\title{
Early Permian Syn-Subduction Extension in the South Tianshan (NW China): Insights From A-Type Granitoids in the Southern Altaids
}

OPEN ACCESS

Edited by:

Xiubin Lin,

Zhejiang University, China

Reviewed by:

Yigui Han,

Northwest University, China; Rui Liu, Shandong University of Technology,

China

${ }^{*}$ Correspondence: Wenjiao Xiao

wj-xiao@mail.iggcas.ac.cn

Specialty section:

This article was submitted to Structural Geology and Tectonics,

a section of the journal

Frontiers in Earth Science

Received: 08 December 2021

Accepted: 27 December 2021

Published: 09 February 2022

Citation:

Abuduxun N, Xiao W, Windley BF, Huang $P$, Yang $H$, Gan J, Sang $M$ and

Liu X (2022) Early Permian Syn-

Subduction Extension in the South Tianshan (NW China): Insights From A-

Type Granitoids in the

Southern Altaids.

Front. Earth Sci. 9:831677.

doi: $10.3389 /$ feart.2021.831677

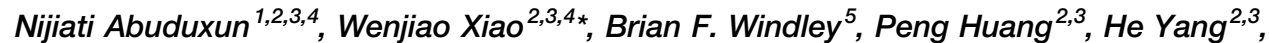
Jingmin Gan ${ }^{2,3,4}$, Miao Sang ${ }^{2,3}$ and Xijun $\mathrm{Li}^{2,3}$

${ }^{1}$ Xinjiang Key Laboratory for Geodynamic Processes and Metallogenic Prognosis of the Central Asian Orogenic Belt, School of Geology and Mining Engineering, Xinjiang University, Urumqi, China, ${ }^{2}$ State Key Laboratory of Desert and Oasis Ecology, Xinjiang Institute of Ecology and Geography, Chinese Academy of Sciences, Urumqi, China, ${ }^{3}$ Xinjiang Key Laboratory of Mineral Resources and Digital Geology, Xinjiang Research Centre for Mineral Resources, Chinese Academy of Sciences, Urumqi, China, ${ }^{4}$ University of Chinese Academy of Sciences, Beijing, China, ${ }^{5}$ School of Geography, Geology and the Environment, The University of Leicester, Leicester, United Kingdom

A-type granite is an important geodynamic indicator because it requires a high melting temperature that is commonly driven by extensional events. Here we report geochronology, whole-rock geochemistry, and zircon Lu-Hf isotopes of newly identified A-type granitic rocks from the South Tianshan in the southern Altaids. Zircon LA-ICP-MS ages indicate that the granitoids were emplaced at ca. 298-272 Ma. Geochemically, they are metaluminous to slightly peraluminous ( $\mathrm{A} / \mathrm{CNK}=0.95-1.10)$, and belong to the high- $\mathrm{K}$ calc-alkaline to shoshonitic series. They are characterized by relatively high zircon saturation temperatures $\left(824-875^{\circ} \mathrm{C}\right), \mathrm{K}_{2} \mathrm{O}+\mathrm{Na}_{2} \mathrm{O}$ contents $(7.31-9.36 \%)$, high field strength elements (HFSE; $\mathrm{Zr}+\mathrm{Nb}+\mathrm{Ce}+\mathrm{Y}=365-802 \mathrm{ppm}$ ), and Ga/Al ratios (2.8-4.2), which all point to an A-type affinity. In addition, they have slightly enriched $\mathrm{Hf}$ isotope compositions $\left(\varepsilon_{\mathrm{Hf}}(\mathrm{t})=-10.9\right.$ to +0.6$)$, and corresponding Mesoproterozoic $(1,272-1759 \mathrm{Ma})$ crustal model ages, suggesting they were probably generated by partial melting of mature crust that contained minor mantle-derived magmatic material. The granitoids have distinctive subduction-related trace element signatures, with deep $\mathrm{Nb}$ and Ta troughs, elevated large ion lithosphere elements (LILEs), and flat HFSEs patterns, very similar to arc-derived granites in the Lachlan accretionary orogen. Integration of these new sedimentological, structural and geochronological results with relevant published information provides a new data-archive, which indicates that neither the Tarim mantle plume nor post-collisional extension can explain the genesis of these A-type granitoids. Instead, we propose a new more pertinent and robust model according to which they formed due to high temperature gradient in a subduction-related extensional setting probably triggered by southward rollback of the South Tianshan oceanic lithosphere, which caused upwelling of asthenospheric mantle combined with an increased temperature that led to large-scale crustal melting. This process gave rise to a broad magmatic arc in the southern active margin of the Yili-Central Tianshan. Our new data shed light on the retreating accretionary orogenesis of the southern Altaids in the Permian.

Keywords: South Tianshan, Altaids, A-type granite, extension, slab roll-back, Permian 


\section{INTRODUCTION}

The Altaids (ca. 600-250 Ma) (Şengör et al., 1993) (Figure 1A) is the younger part of the Central Asian Orogenic Belt $(1.0 \mathrm{Ga}-$ $250 \mathrm{Ma}$ ) (Windley et al., 2007; Xiao et al., 2015), one of the largest accretionary orogens on the planet, which contains a record of the most intense period of accretionary growth in the PaleozoicMesozoic (Şengör et al., 1993; Windley et al., 2007; Xiao et al., 2020). It grew southwards from the Siberian Craton by the successive accretion of multiple arcs, accretionary complexes and micro-continents (e.g., Windley et al., 2007; Xiao et al., 2009; Safonova et al., 2017; Yakubchuk, 2017; Li et al., 2018), followed by its final amalgamation with the Tarim and North China Cratons along the South Tianshan and Solonker sutures (Xiao et al., 2003, 2014). Accordingly, the South Tianshan was subjected to the latest collisional event in the southern Altaids (Xiao et al., 2013; Han et al., 2016; Abuduxun et al., 2021a), and consequently provides critical constraints on the termination of accretion.

Permian magmatic rocks are widespread in the western Tianshan (Figure 1B; Supplementary Table S1), petrogenesis of which has long been an issue of hot debate that has hampered a better understanding of the latest stages of evolution of the southern Altaids. The main models to explain formation of the Permian felsic magmatism in the South Tianshan include: 1. a post-collisional extensional setting related to pre-Permian closure of the South Tianshan ocean (Konopelko et al., 2007; Long et al., 2008; Seltmann et al., 2011; Huang et al., 2015a; Qin et al., 2021). 2. A result of the Permian Tarim mantle plume (e.g., Zhang and Zou, 2013). Although it is well accepted that the South
Tianshan was still under a subduction regime in the Permian (Li et al., 2005; Xiao et al., 2013; Sang et al., 2018; Wen et al., 2020; Abuduxun et al., 2021a), less attention has been paid to the petrogenesis of the Permian granitoids in relevant tectonic models. Thus, these conflicting views have created an important, but unresolved question, which is critical for understanding the Permian accretionary architecture of the southern Altaids.

A-type granites generally require a high melting temperature, which is commonly driven by extensional events, such as continental rifting and/or post-collisional extension (Whalen et al., 1987; Eby, 1992). Moreover, several recent studies have pointed out that A-type granites can also occur in a subductionrelated extensional setting (e.g., Collins et al., 2019; Yin et al., 2021). Therefore, the A-type granites in ancient accretionary orogens are important petrogenetic indicators, which provide crucial information for unravelling their ambient geodynamic processes.

So far, Permian A-type granites have not been well documented in the Chinese part of the South Tianshan; the main examples are in Kyrgyzstan (Figure 1B). Nevertheless, their spatiotemporal relations to coeval magmatism in adjacent tectonic units is not well constrained, although they are usually considered to be post-collisional (Konopelko et al., 2007; Konopelko et al., 2009).

In this study, we report zircon $\mathrm{U}-\mathrm{Pb}$ geochronology, Lu-Hf isotopes and whole rock geochemistry of newly-identified A-type granitoids from key locations in the South Tianshan. By integration of current and previously published data, we propose that upper-plate extension triggered by slab rollback was the geodynamic process that was responsible for the spatially

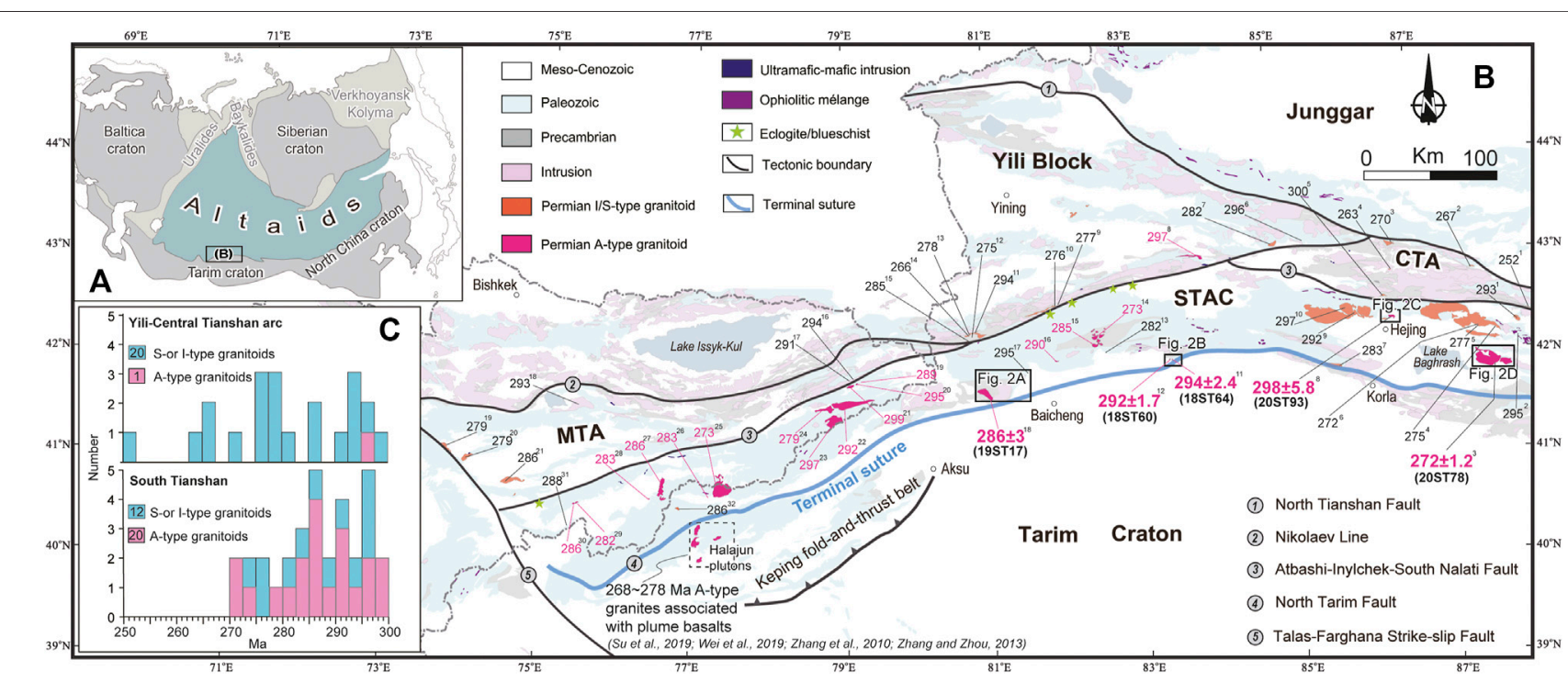

FIGURE 1 | (A) Simplified tectonic map showing the Altaids and surrounding cratons (modified after Şengör et al., 1993), Figure 1B is outlined (B) Simplified map of the South Tianshan (modified after Huang et al., 2018) showing compiled crystallization ages of Permian granitoids (see Supplementary Table S1 for details and data sources), the positions of Figures 2A-D are marked (C) Histograms for compiled crystallization ages of the coeval Permian granitoids in the Yili-Central Tianshan block and the South Tianshan orogen. Right superscripts in Figure 1B represent numbers of each item listed in Supplementary Table S1, ages obtained in this study are shown in bold. Light blue thick line represents the terminal suture between the Tarim Craton and the Yili-Central Tianshan arc (Abuduxun et al., 2021a). Abbreviation: CTA, Central Tianshan Arc (in China); MTA, Middle Tianshan Arc (in Kyrgyzstan); STAC, South Tianshan Accretionary Complex. 


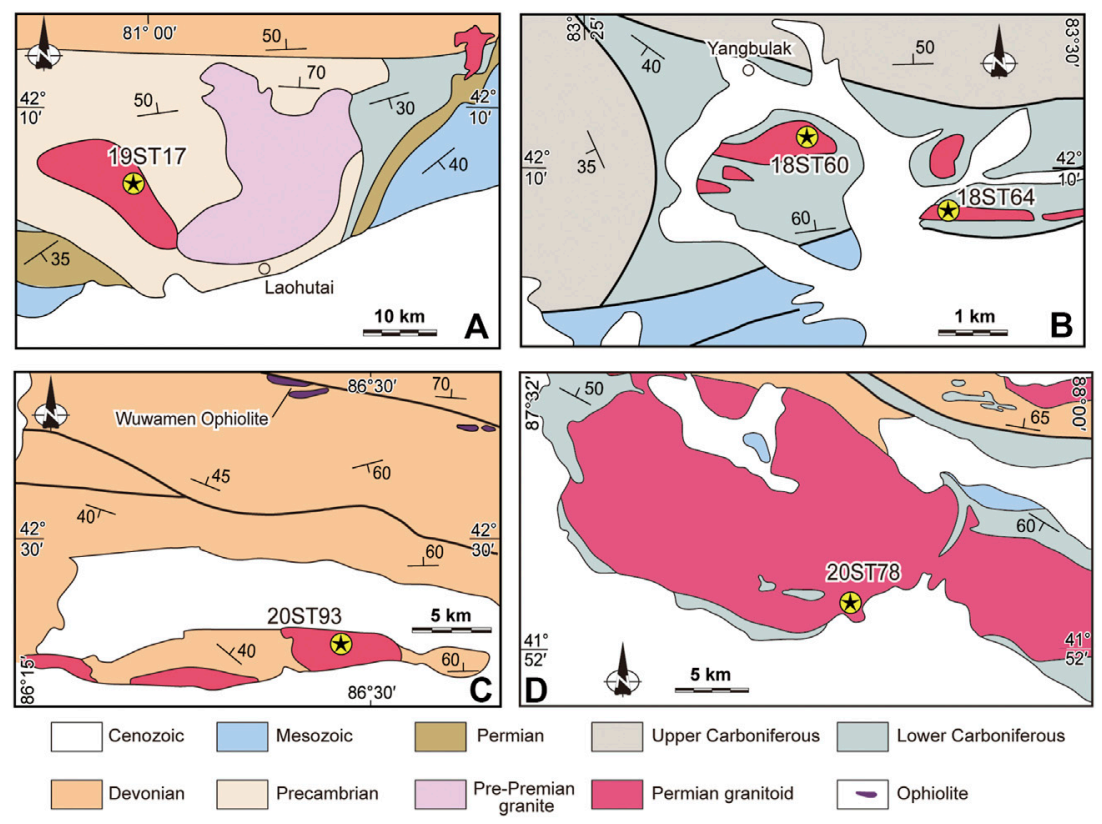

FIGURE 2 | Simplified geological maps of studied areas showing distribution of Permian granitoids and sampling sites. (A) Geological map of the Laohutai area (modified after Wang, 2007a); (B) Geological map of the Yangbulak area (modified after BGMRXUAR, 1975a); (C) Geological map of the Hejing area (modified after BGMRXUAR, 1975b); (D) Geological map of the area east of Lake Baghrash (modified after BGMRXUAR, 1965).

and temporally-related Early Permian granitoids in the South Tianshan. Our data provide new insights for the retreating accretionary orogenesis of the southern Altaids before its final amalgamation with the Tarim Craton.

\section{GEOLOGICAL FRAMEWORK}

Tectonic units referred in this study include from north to south: the Yili-Central Tianshan arc, the South Tianshan accretionary complex, and the northern Tarim Craton (Figure 1B).

The Yili-Central Tianshan arc, separated from the South Tianshan by the Atbashi-Inylchek-South Nalati Fault (Figure 1B), is a Paleozoic magmatic arc located along the Southern Yili block, the Central Tianshan (in China) and the Middle Tianshan (in Kyrgyzstan) (Figure 1B) (Abuduxun et al., 2021a; Han et al., 2011; Xiao et al., 2013); these units record significant accretion-collision events related to closure of the South Tianshan ocean (Alekseev et al., 2009; Gao et al., 2009). This Paleozoic arc, which is mainly underlain by Mesoproterozoic ( 1.4 Ga) to Neoproterozoic (969-708 Ma) basement rocks (e.g., He et al., 2015; Huang et al., 2017), is mostly composed of arc-related calk-alkaline plutonic and volcanic rocks with ages of 490-308 Ma (e.g., Alekseev et al., 2009; Gao et al., 2009; Su et al., 2021; Wang et al., 2020). In addition, throughout the Yili-Central Tianshan there are widely exposed Permian (298-252 Ma) granitoids that intruded into pre-Permian igneous and sedimentary rocks (Figure 1B; Supplementary Table S1). These granitoids were previously interpreted to be: 1) post-collisional intrusions generated during lithospheric delamination (e.g., Ma et al., 2015; Wang et al., 2018a); 2) bodies genetically related to the Tarim mantle plume (e.g., Zhang and Zou, 2013); and 3) subduction-related magmatic rocks (Xiao et al., 2013; Mao et al., 2021).

The South Tianshan accretionary complex, formed as a result of continuous northward subduction of the South Tianshan oceanic plate (Abuduxun et al., 2021a; Sang et al., 2018; Xiao et al., 2013), followed by final amalgamation of the Tarim Craton with the Yili-Central Tianshan arc (Alexeiev et al., 2015; Han et al., 2011) (Figure 1B). Accordingly, it records the process of terminal suturing, in the southern Altaids, between the YiliCentral Tianshan arc and the northern passive margin of the Tarim Craton (Han et al., 2011; Xiao et al., 2013).

The principal strata in the South Tianshan are Paleozoic siliciclastic turbidites, limestones, cherts and schists (BGMRXUAR, 1993). They were previously considered to be passive margin sediments on the northern slope of the Tarim Craton (Han et al., 2011; Biske et al., 2018). Recently, however, fragmented and/or dismembered elements of ocean plate stratigraphy (OPS) were recognized in previously assigned Silurian to Carboniferous strata from several locations in the South Tianshan (Safonova et al., 2016; Sang et al., 2018; Abuduxun et al., 2021a, 2021b). They are composed of closely associated MORB/OIB-type basalts, ribbon cherts and turbidites that occur in mélanges with a typical block-in-matrix structure or in coherent strata in thrust-repeated tectonic slices (Sang et al., 2018; Abuduxun et al., 2021b). The depositional ages of the Paleozoic strata, especially of metamorphosed sediments, are younger than previously estimated, as indicated by new ages of detrital zircons ( Fu et al., 2018; Huo et al., 2019; Abuduxun et al., 2021a). Provenance 
TABLE 1 | Simple petrological descriptions, ages and zircon saturation temperatures of Permian granitoids investigated in this study

\begin{tabular}{|c|c|c|c|c|c|}
\hline Sample & Lithology & Major minerals ${ }^{a}$ & Age/Ma & $\mathbf{T}_{\boldsymbol{Z r}} /{ }^{\circ} \mathrm{C}$ & Gps \\
\hline 18ST60 & Granite porphyry & Phenocrysts: Kfs: 20-25\%, Pl: 20-25\%, Qtz: 10-15\%, Bt: 5-10\% & $292 \pm 2.6$ & 849 & $\begin{array}{l}\mathrm{N} 42^{\circ} 10^{\prime} 27^{\prime \prime} \\
\mathrm{E} 83^{\circ} 27^{\prime} 58^{\prime \prime}\end{array}$ \\
\hline 18ST64 & Granite porphyry & $\begin{array}{l}\text { Phenocrysts: Pl: 10-15\%, } \\
\text { Qtz: 5-10\% }\end{array}$ & $294 \pm 2.4$ & 852 & $\begin{array}{l}\mathrm{N} 42^{\circ} 09^{\prime} 54^{\prime \prime} \\
\mathrm{E} 83^{\circ} 29^{\prime} 08^{\prime \prime}\end{array}$ \\
\hline $19 S T 17$ & Syenogranite & $\begin{array}{l}\text { Kfs: } 45-50 \% \text {, Pl: } 10-15 \% \text {, } \\
\text { Qtz: } 25-30 \%, B t: ~ 5 \%\end{array}$ & $286 \pm 3.0$ & 871 & $\begin{array}{l}\mathrm{N} 41^{\circ} 55^{\prime} 35^{\prime \prime} \\
\mathrm{E} 80^{\circ} 52^{\prime} 43^{\prime \prime}\end{array}$ \\
\hline 20ST78 & Biotite monzogranite & $\begin{array}{l}\text { Kfs:30-35\%, Pl: } 25-30 \% \\
\text { Qtz: } 20-25 \%, \text { Bi: } ~ 10 \%\end{array}$ & $272 \pm 1.2$ & 865 & $\begin{array}{l}\mathrm{N} 41^{\circ} 50^{\prime} 56^{\prime \prime} \\
\mathrm{E} 87^{\circ} 43^{\prime} 25^{\prime \prime}\end{array}$ \\
\hline 20ST93 & Granodiorite & $\begin{array}{l}\text { Kfs: } 15-20 \% \text {, Pl: } 35-40 \% \text {, } \\
\text { Qtz: } 25 \% \text {, Bt and Arf: 15\% }\end{array}$ & $298 \pm 5.8$ & 824 & $\begin{array}{l}\mathrm{N} 42^{\circ} 26^{\prime} 26^{\prime \prime} \\
\mathrm{E} 86^{\circ} 31^{\prime} 10^{\prime \prime}\end{array}$ \\
\hline
\end{tabular}

${ }^{a}$ Kfs = K-feldspar; PI = plagioclase; $Q t z=$ quartz; Bt = biotite; Arf = arfvedsonite

analysis of the clastic sedimentary rocks indicates that they were mainly derived from the Yili-Central Tianshan arc (Sang et al., 2018; Huo et al., 2019; Abuduxun et al., 2021a).

Ophiolite mélanges scattered as exotic slices in Paleozoic strata range in age from Cambrian to Late Carboniferous based on available geochronological data (500-330 Ma) (e.g., Wang et al., 2011; Jiang et al., 2014; Hegner et al., 2020) and on microfossil ages (e. g. Middle Devonian to Early Carboniferous radiolaria and conodonts) (e.g., Han et al., 2011; Sang et al., 2020a). The youngest microfossils are Late Permian radiolaria reported from the Baleigong ophiolite (Li et al., 2005). These rocks were interpreted either as supra-subduction zone (SSZ) ophiolites that formed in back-arc basins (Wang et al., 2011; Jiang et al., 2014), or as MOR-type ophiolites from a wide ocean (Wang et al., 2018b). Some ophiolites with OIB-type basalts and associated limestones were interpreted as fragments of accreted seamounts (Yang et al., 2018; Sang et al., 2020b; Wan et al., 2020). In addition, eclogites and blueschists in ophiolite mélanges at Akeyazi, NW China (Gao and Klemd, 2000) and at Atbashi, Kyrgyzstan (Hegner et al., 2011) occur in a well-documented (ultra-)-high-pressure metamorphic belt in the South Tianshan (Zhang et al., 2019a).

Magmatic rocks in the South Tianshan are of two main types: Late Silurian to Early Devonian arc-type plutonic and volcanic rocks (e.g., Lin et al., 2013; Qin et al., 2016), and Late Carboniferous to Permian bimodal volcanic rocks and granitoids (e.g., Konopelko et al., 2007, 2009; Ma et al., 2015; Cheng et al., 2017).

The basement of the Tarim Craton, which is mainly exposed in surrounding blocks, such as Quruqtagh and Altyn, consists predominantly of Archean to Paleoproterozoic tonalitetrondhjemite-granodiorite (TTG) gneisses, amphibolites, granitoids, mafic dykes, bimodal volcanic rocks and metasedimentary rocks (e.g., Long et al., 2010; Ge et al., 2020). They are unconformably overlain by Middle to Late Neoproterozoic siliciclastic and volcanic rocks with interbedded glacial diamictites and minor carbonates (BGMRXUAR, 1993), and emplaced by Neoproterozoic granitoids and by mafic layered intrusions (e.g., Shu et al., 2011). Well-exposed Paleozoic to Mesozoic strata that are dominated by shallow-marine carbonates, sandstones and conglomerates overlie the Precambrian rocks of the Tarim Craton (BGMRXUAR, 1993; Dong et al., 2016).

Intensive Permian (292-286 Ma) basaltic lavas and maficultramafic complexes covering an area of more than $2.5 \times$
$10^{5} \mathrm{~km}^{2}$ are ascribed to a mantle plume (Zhang et al., 2010). Plume-related felsic intrusions that are mainly composed of 278-268 Ma syenites and A-type granites (Figure 1B) (Zhang and Zou, 2013; Su et al., 2019; Wei et al., 2019) are closely associated with mafic-ultramafic igneous rocks (Zhang et al., 2010) or with alkali mafic dykes (Zou et al., 2015).

\section{SAMPLING AND BRIEF PETROGRAPHY}

The regional distribution of the Permian granitoids in the South Tianshan is shown in Figure 1B. They mainly occur in stocks of variable size that have intruded pre-Permian rocks along the strike of the South Tianshan (BGMRXUAR, 1993). Samples for zircon U-Pb dating, Lu-Hf-isotope and whole rock geochemical analysis were collected from five intrusions in the South Tianshan (Figures 1B, 2). The lithologies, petrological compositions and sampling coordinates of the investigated granitoids are briefly summarized in Table $\mathbf{1}$.

Sample 19ST17 was collected from a coarse-grained syenogranite (Figure 3C) in the Laohutai area (Figure 2A). As shown in Figure $3 \mathbf{H}$, it consists mainly of K-feldspar (45-50\%), plagioclase (10-15\%), quartz (25-30\%), and minor biotite ( 5\%). Accessory minerals include zircon and apatite. The wall rock of the pluton was ascribed to the Mesoproterozoic Akesu Group according to previous investigations (BGMRXUAR, 1982; Wang, 2007a). However, it is worth noting that the depositional ages of these "old" rocks were commonly estimated by stratigraphic correlations and/or on their degree of metamorphism. Recent age data suggest these rocks are not older than Paleozoic (Huo et al., 2019).

Samples 18ST60 and 18ST64 are from two granite porphyries in the Yangbulak area (Figure 2B), both of which intruded Upper Carboniferous sandstones (Figure 3A, Abuduxun et al., 2021a); not Lower Carboniferous as previously assigned (BGMRXUAR, 1975a). The samples show clear porphyritic textures (Figures 3A,B), and contain phenocrysts mainly composed of K-feldspar, plagioclase, quartz and biotite (Figures 3F,G).

Sample 20ST93 is from a medium-grained granodiorite stock (Figure 3E) exposed $10 \mathrm{Km}$ north of the Hejing county (BGMRXUAR, 1975b). It has intruded Devonian metasedimentary schists, phyllites and marbles (Figure 2C; BGMRXUAR, 1975b). As shown in Figure 3J, the sample comprises K-feldspar (15-20\%), plagioclase (35-40\%), quartz $(\sim 25 \%)$, biotite $(5-10 \%)$ and minor arfvedsonite. 


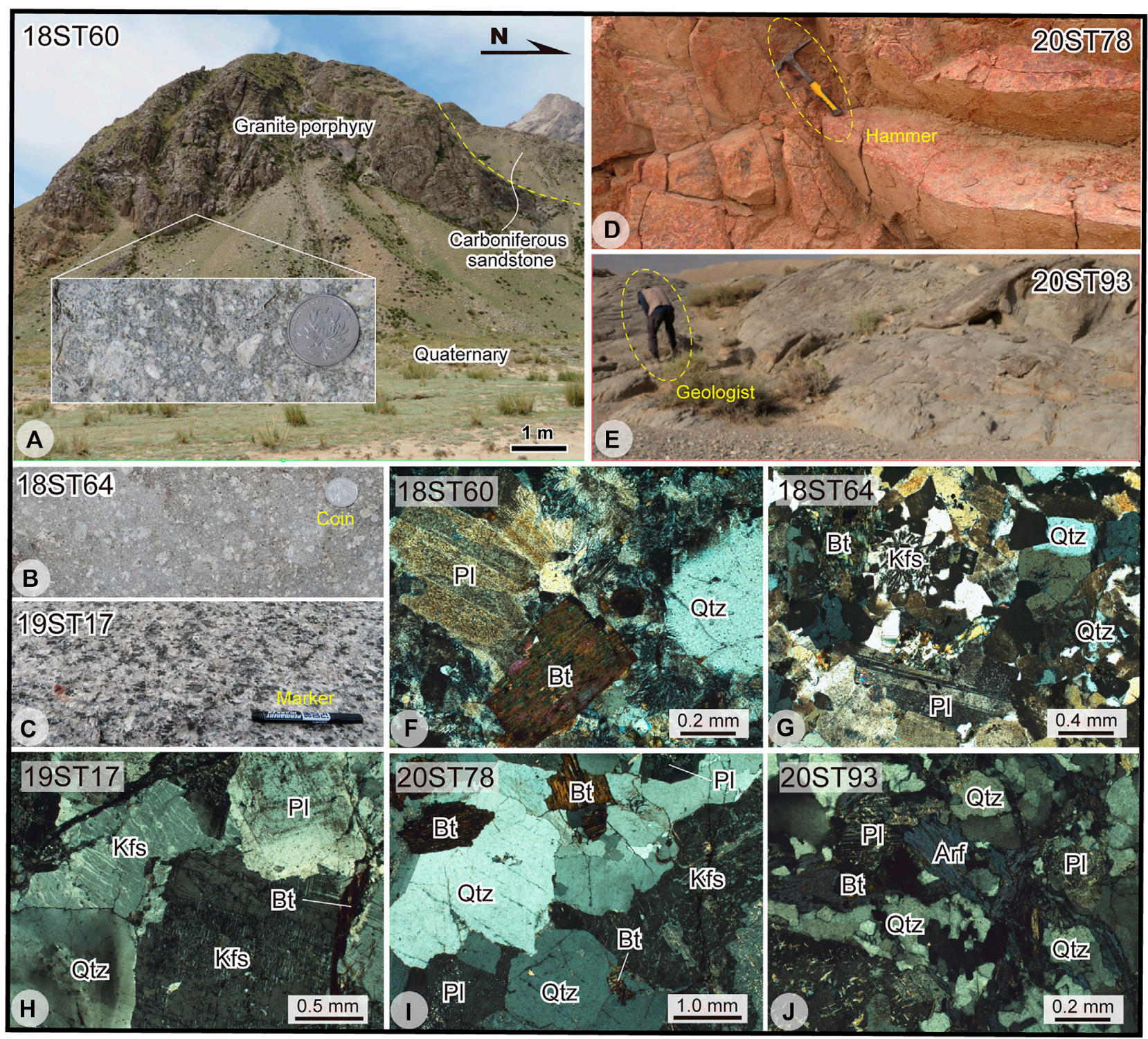

FIGURE 3 | (A) A field photo showing that the granite porphyry intruded Carboniferous sandstones in the Yangbulak area; (B-E) Outcrops and field occurrences of the Permian granitoids; (F-J) photomicrographs showing the main mineral compositions. Abbreviation: Bt, biotite; Kfs, K-feldspar; Pl, plagioclase; Qtz, quartz; Arf, arfvedsonite.

Sample 20ST78 is from a coarse-grained biotite monzogranite (Figure 3D) exposed east of Lake Baghrash (BGMRXUAR, 1965); it has intruded Carboniferous sandstones (Figure 2D). Figure 3I shows that it contains K-feldspar (30-35\%), plagioclase (25-30\%), quartz $(20-25 \%)$, biotite $(\sim 10 \%)$. Besides, accessory minerals include $\mathrm{Fe}-\mathrm{Ti}$ oxides.

\section{ANALYTICAL METHODS}

\subsection{Zircon U-Pb Geochronology}

Zircon mounts and cathodoluminescence (CL) images were made at Beijing Zhongke Kuangyan Test Technology Co., Ltd. Each sample was crushed, and its zircon grains were separated using standard magnetic and high-density liquid techniques. The zircons were handpicked and cast in an epoxy mount, which was polished to expose their interiors for imaging by optical and CL techniques. The mounts were subsequently polished to EBSD standard using collodial silica and carbon coating. A Tescan MIRA 3 field emission scanning electron microscope (SEM) was used to collect CL images of individual zircon grains.

Zircon U-Pb analyses were made at the Beijing Quick-Thermo Science \& Technology Co., Ltd, using an ESI New Wave NWR $193^{\mathrm{UC}}$ (TwoVol2) laser ablation system connected to an Agilent 8900 ICP-QQQ. Individual zircon grains (mounted and polished in epoxy) were ablated in a constant stream of He that was mixed downstream with $\mathrm{N}_{2}$ and Ar before entering the torch region of the ICP-QQQ. After warmup of the ICP-QQQ and connection 

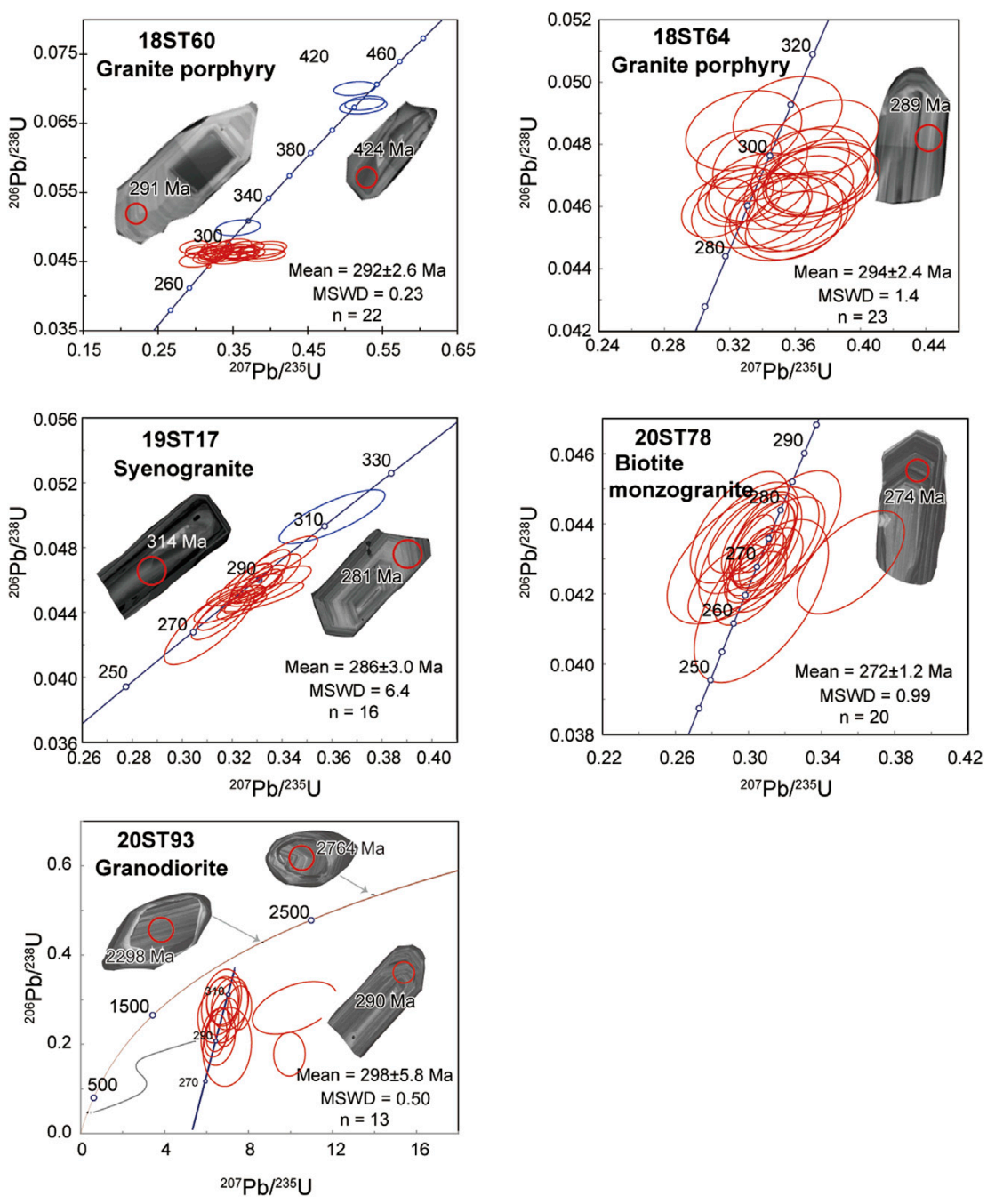

FIGURE 4 | U-Pb Concordia diagrams and representative cathodoluminescence (CL) images of zircons from the Permian granitoids in this study. Ages are in Ma and ellipses show $1 \sigma$ errors. Red circles indicate positions of dated laser spots. Ellipses in blue represent ages of inherited zircons, and consequently were excluded in the calculations of weighted mean ages.

with the laser ablation system, the ICPMS was first tuned for robust plasma conditions by optimizing laser and ICP-QQQ settings, and for monitoring ${ }^{232} \mathrm{Th}^{16} \mathrm{O}^{+} /{ }^{232} \mathrm{Th}^{+}$ratios (always $\leq 0.2 \%$ ) and ${ }^{238} \mathrm{U}^{+} /{ }^{232} \mathrm{Th}^{+}$ratios (always between 0.95 and 1.05) while ablating NIST SRM 612 in line-scan mode. 91500zircon was used as a primary reference material for $\mathrm{U}-\mathrm{Pb}$ age determinations, and PleŠovice zircon (Mean = $337 \pm 1.2 \mathrm{Ma}$; MSWD $=0.95$ ) as a secondary reference (Wiedenbeck et al., 1995). Background subtractions and corrections for laser downhole elemental fractionation were undertaken with the Iolite data reduction package within the Wavemetrics Igor Pro data analysis software (Paton et al., 2010). Concordia diagrams were processed using ISOPLOT 4.15 (Ludwig, 2003).

\subsection{Hf Isotopes}

Zircon Hf isotope analyses were carried out in situ using a Geolas HD excimer ArF laser ablation system attached to a Neptune Plus
(Thermo Fisher, Germany) Multi-Collector Inductively Coupled Plasma Mass Spectrometry (MC-ICP-MS) at the Guangxi Key Laboratory of Hidden Metallic Ore Deposits Exploration, Guilin University of Technology.

All data were acquired on zircons in single spot ablation mode at a spot size of $44 \mu \mathrm{m}$. Helium was used as a carrier gas to transport ablated samples from the laser-ablation cell to the ICPMS torch by a mixing chamber merged with Argon The energy density of laser ablation used in the present study was $\sim 7.0 \mathrm{~J} \mathrm{~cm}^{-2}$. Each measurement consisted of $18 \mathrm{~s}$ of acquisition of the background signal followed by $50 \mathrm{~s}$ of ablation signal acquisition. ${ }^{176} \mathrm{Lu} /{ }^{175} \mathrm{Lu}=0.02656$ (Blichert-Toft et al., 1997) and ${ }^{176} \mathrm{Yb} /{ }^{173} \mathrm{Yb}=0.79639$ (Fisher et al., 2014) ratios were determined in order to correct the isobaric interferences of ${ }^{176} \mathrm{Lu}$ and ${ }^{176} \mathrm{Yb}$ on ${ }^{176} \mathrm{Hf}$. Hf and $\mathrm{Yb}$ isotope ratios were normalized to ${ }^{179} \mathrm{Hf} /{ }^{177} \mathrm{Hf}=0.7325$ and ${ }^{173} \mathrm{Yb} /{ }^{171} \mathrm{Yb}=$ 1.132685 (Fisher et al., 2014) using an exponential correction 
for mass bias. Zircon GJ1 was used as the reference standards during the routine analyses. Off-line selection and integration of analyzed signals, and mass bias calibrations were performed using ICPMSDataCal (Liu et al., 2010).

The $\varepsilon_{\mathrm{Hf}}(\mathrm{t})$ values were calculated by assuming chondritic values of ${ }^{176} \mathrm{Lu} /{ }^{177} \mathrm{Hf}=0.282785$ and ${ }^{176} \mathrm{Hf} /{ }^{177} \mathrm{Hf}=0.0336$ (Bouvier et al., 2008). The single-stage model ages $\left(T_{\mathrm{DM} 1}\right)$ were calculated relative to the depleted mantle with a presentday ${ }^{176} \mathrm{Hf} /{ }^{177} \mathrm{Hf}=0.28325$ and ${ }^{176} \mathrm{Lu} /{ }^{177} \mathrm{Hf}=0.0384$ (Griffin et al., $2000)$. The two-stage continental crust model ages $\left(T_{\mathrm{DM} 2}\right)$ were also calculated by plotting the initial ${ }^{176} \mathrm{Hf} /{ }^{177} \mathrm{Hf}$ of zircons back to the depleted mantle evolutionary curve using the value of ${ }^{176} \mathrm{Lu} /{ }^{177} \mathrm{Hf}(0.015)$ for the average continental crust (Griffin et al., 2000). The calculated $\varepsilon_{\mathrm{Hf}}(\mathrm{t})$ values and two-stage model $\left(T_{\mathrm{DM} 2}\right)$ were compiled using the zircon ${ }^{206} \mathrm{~Pb} /{ }^{238} \mathrm{U}$ ages.

\subsection{Whole Rock Geochemistry}

The geochemical analysis of the bulk-rock samples was performed at the ALS Chemex Co. Ltd in Guangzhou. All samples were crushed to less than 200-mesh after removal of weathered surfaces and then mixed with $\mathrm{Li}_{2} \mathrm{~B}_{4} \mathrm{O}_{7}$ and $\mathrm{LiBO}_{2}$ to make homogeneous glass beans at $1,050-1,100{ }^{\circ} \mathrm{C}$. Major elements were determined by XRF-1500 Sequential X-ray Fluorescence Spectrometry on fused glass beads, the analytical precision of which ranged from $\pm 1 \%$ to $\pm 2 \%$ based on certified standards and duplicate analyses.

Trace elements and Rare Earth Elements (REE) were analyzed with an inductively-coupled Plasma Mass Spectrometer (ICPMS). About $50 \mathrm{mg}$ of powder for every sample were added to a lithium metaborate flux, mixed well and fused in a furnace at $1,000^{\circ} \mathrm{C}$. The resulting melt was then cooled and dissolved in $100 \mathrm{ml}$ of $4 \% \mathrm{HNO} 3$ solution. The analytical precision of the ICPMS data at the ppm level is better than $5 \%$.

\section{RESULTS}

\subsection{Zircon U-Pb Ages and Hf Isotopes}

The results of zircon $\mathrm{U}-\mathrm{Pb}$ dating are listed in Supplementary Table S2, and are graphically illustrated in Figure 4. The results of in-situ Lu-Hf isotopes are listed in Supplementary Table S3, and are graphically visualized in Figures 5, 6. Representative cathodoluminescence (CL) images are also shown in Figure 4.

The CL images show that zircons separated from all dated samples are transparent to semitransparent, and mostly have euhedral and prismatic morphologies with clear oscillatory zones and aspect ratios of 1:2-1.3 in CL images (Figure 4), indicative of a magmatic origin. They mostly show high $\mathrm{Th} / \mathrm{U}$ ratios (from 0.3 to 1.92), further indicating a magmatic origin (Corfu et al., 2003).

A total of 26 analyses were conducted of the granite porphyry sample 18ST60, among which 22 grains have concentrated ${ }^{206} \mathrm{~Pb} /$ ${ }^{238} \mathrm{U}$ ages between 287 and $298 \mathrm{Ma}$, yielding a weighted mean ${ }^{206} \mathrm{~Pb} /{ }^{238} \mathrm{U}$ age of $292 \pm 2.6 \mathrm{Ma}$ (MSWD $=0.23$ ); this age is interpreted as the crystallization age of this sample. The remaining 4 grains yield concordant older ages of $314 \mathrm{Ma}$, $421 \mathrm{Ma}, 424 \mathrm{Ma}$, and $436 \mathrm{Ma}$, which might be inherited zircons or were captured from the wall rock during magma

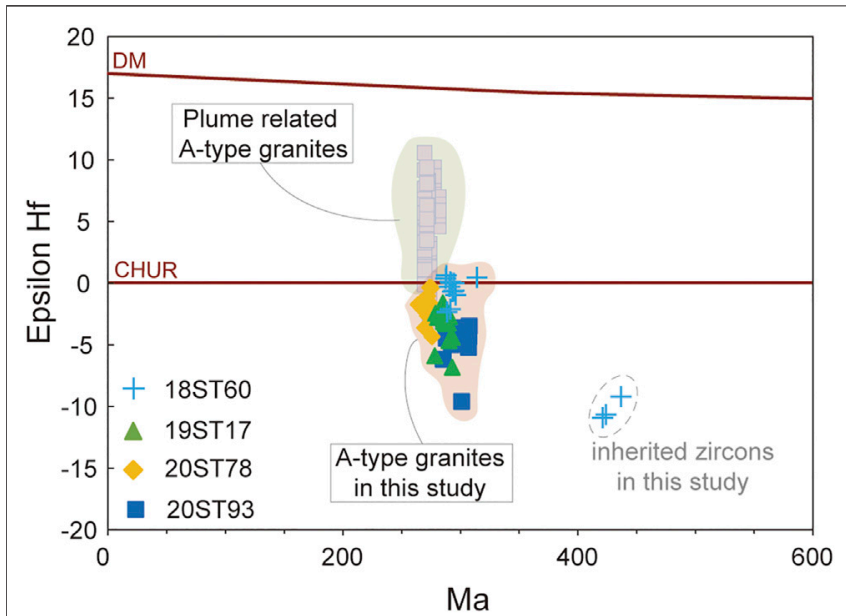

FIGURE 5 | Temporal variations of zircon $\varepsilon_{\mathrm{Hf}}(\mathrm{t})$ values showing the contrasting difference in the magma source between the Permian A-type granitoids in the South Tianshan that mostly have negative $\varepsilon_{\mathrm{Hf}}(\mathrm{t})$ values (Supplementary Table S3) and the Permian Tarim plume-related A-type granites that have apparent positive $\varepsilon_{\mathrm{Hf}}(\mathrm{t})$ values (data sources are can be found in Su et al., 2019; Wei et al., 2019; Zhang et al., 2010).

ascent. Sixteen spots on the dated zircons were analyzed for their Hf isotopic compositions. Twelve grains with Permian ages display $\varepsilon_{\mathrm{Hf}}(\mathrm{t})$ values ranging from -2.3 to 0.6 (Figure 5), corresponding to $\left(T_{\mathrm{DM} 2}\right)$ ages between 1,272 and 1,461 Ma. An inherited $314 \mathrm{Ma}$ zircon displays a similar $\varepsilon_{\mathrm{Hf}}(\mathrm{t})$ value $(+0.5)$ and corresponding $\left(T_{\mathrm{DM} 2}\right)$ age $(1,303 \mathrm{Ma})$ as the Permian zircons. In contrast, the three other inherited zircons $(421,424,436 \mathrm{Ma})$ show more negative $\varepsilon_{\mathrm{Hf}}(\mathrm{t})$ values of -10.9 to -9.2 (Figure 5), with corresponding older $\left(T_{\mathrm{DM} 2}\right)$ ages of 2010-2,106 Ma (Figure 6).

A total of 23 analyses of the granite porphyry sample 18ST64 yield concordant ages between 286 and $308 \mathrm{Ma}$, and define a weighted mean ${ }^{206} \mathrm{~Pb} /{ }^{238} \mathrm{U}$ age of $294 \pm 2.4 \mathrm{Ma}(\mathrm{MSWD}=1.4)$. This age is considered as the crystallization age of sample 18ST64.

Out of the 17 analyses of the syenogranite sample 19ST17, one was performed on an inherited or captured zircon with a concordant older age of $314 \mathrm{Ma}$. The remaining 16 spots yield a weighted mean ${ }^{206} \mathrm{~Pb} /{ }^{238} \mathrm{U}$ age of $286 \pm 3.0 \mathrm{Ma}(\mathrm{MSWD}=6.4)$, which is considered to be the crystallization age of this sample; fourteen in-situ Lu-Hf analyses were obtained for this sample. The results display negative $\varepsilon_{\mathrm{Hf}}(\mathrm{t})$ values of -6.8 to -1.6 (Figure 5), corresponding to $\left(T_{\mathrm{DM} 2}\right)$ ages of $1,411-1759 \mathrm{Ma}$.

A total of 20 analyses of the biotite monzogranite sample 20ST78 comprise an age range of 264-277 Ma, with a weighted mean ${ }^{206} \mathrm{~Pb} /{ }^{238} \mathrm{U}$ age of $272 \pm 1.2 \mathrm{Ma}(\mathrm{MSWD}=0.99)$; this is interpreted as the crystallization age of the biotite monzogranite. All twenty spots were analyzed for their Hf isotopic compositions. The data show slightly negative $\varepsilon_{\mathrm{Hf}}(\mathrm{t})$ values of -4.3 to -0.4 (Figure 5), with corresponding $\left(T_{\mathrm{DM} 2}\right)$ ages between 1,324 and $1,579 \mathrm{Ma}$

Out of the 15 analyses of the granodiorite sample 20ST93, two were performed on the inherited or captured zircons with prominent older ages of 2,298 Ma and 2,764 Ma. The 


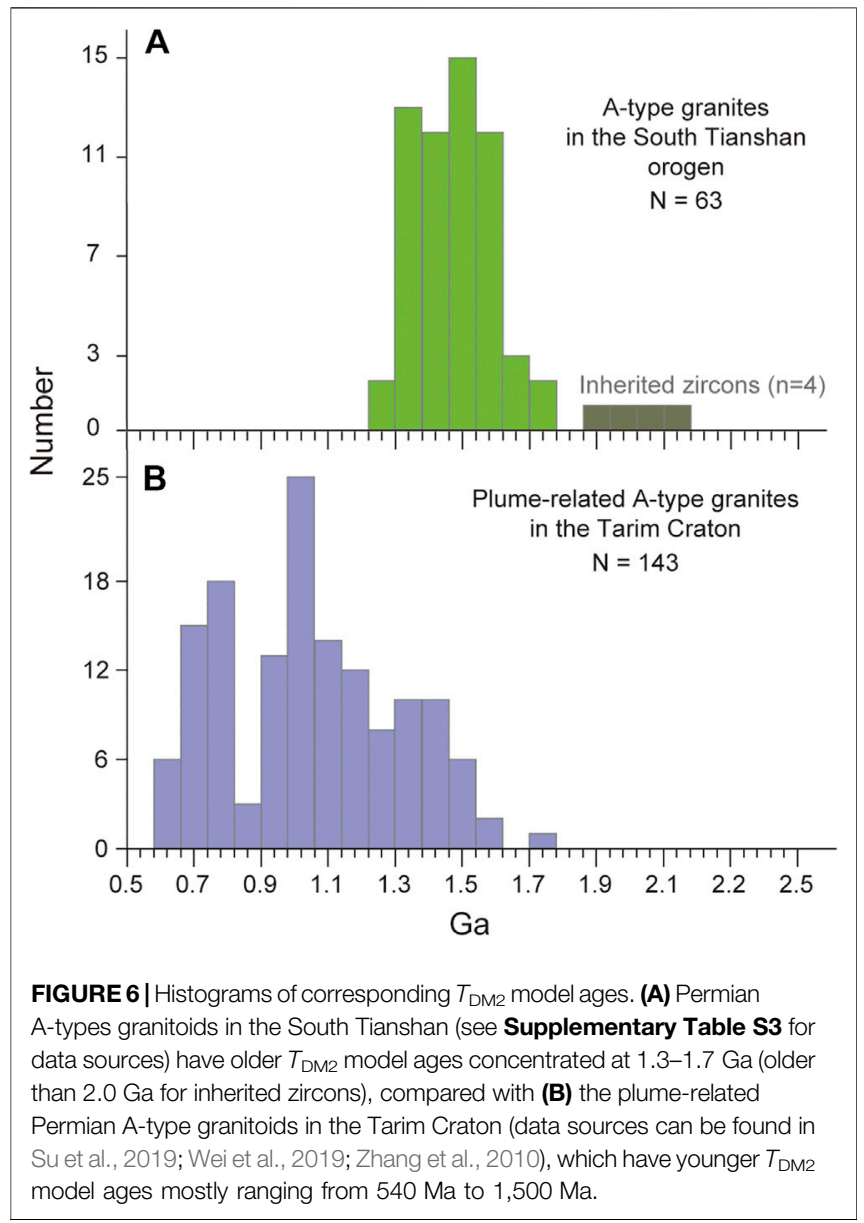

remaining 13 analyses yield a weighted mean ${ }^{206} \mathrm{~Pb} /{ }^{238} \mathrm{U}$ age of $298 \pm 5.8 \mathrm{Ma}(\mathrm{MSWD}=0.50)$ representing the crystallization age of this sample. With the exception of two Precambrian inherited zircons, the remaining thirteen grains with Permian ages were analyzed for $\mathrm{Hf}$ isotopic compositions. The results display negative $\varepsilon_{\mathrm{Hf}}(\mathrm{t})$ values between -9.6 and -3.5 (Figure 5), with corresponding $\left(T_{\mathrm{DM} 2}\right)$ ages ranging from 1,548 to $1932 \mathrm{Ma}$.

\subsection{Whole Rock Geochemistry}

The results of major and trace element geochemical analyses of the Permian granitoids are listed in Supplementary Table S4.

Samples 18ST60, 18ST64, 19ST17 and 20ST78 generally show $\mathrm{SiO}_{2}$ contents ranging from 69.25 to 78.20 wt.\% and $\mathrm{K}_{2} \mathrm{O}+\mathrm{Na}_{2} \mathrm{O}$ contents between 7.95 and $9.36 \mathrm{wt} . \%$, and they plot in the granite field in the total alkalis $\left(\mathrm{K}_{2} \mathrm{O}+\mathrm{Na}_{2} \mathrm{O}\right)$ wt.\% vs. silica $\left(\mathrm{SiO}_{2}\right.$ wt.\%) classification diagram for plutonic rocks (Figure 7A) (Cox et al., 1979). In addition, these samples are characterized by low to moderate concentrations of $\mathrm{Al}_{2} \mathrm{O}_{3}$ (11.11-14.07 wt.\%), $\mathrm{TiO}_{2}$ (0.15-0.46 wt.\%), $\mathrm{CaO}$ (0.22-1.70 wt.\%), $\mathrm{MgO}$ (0.12-0.48 wt.\%) and $\mathrm{P}_{2} \mathrm{O}_{5}$ (0.12-0.15 wt.\%). In comparison, sample 20ST93 exhibits relatively lower $\mathrm{SiO}_{2}$ contents ranging from 65.71 to 66.81 wt.\% and high $\mathrm{K}_{2} \mathrm{O}+\mathrm{Na}_{2} \mathrm{O}$ contents between 7.31 and 7.85 wt.\%, and they plot on the boundary between the granodiorite and granite fields in the classification diagram (Figure 7A) (Cox
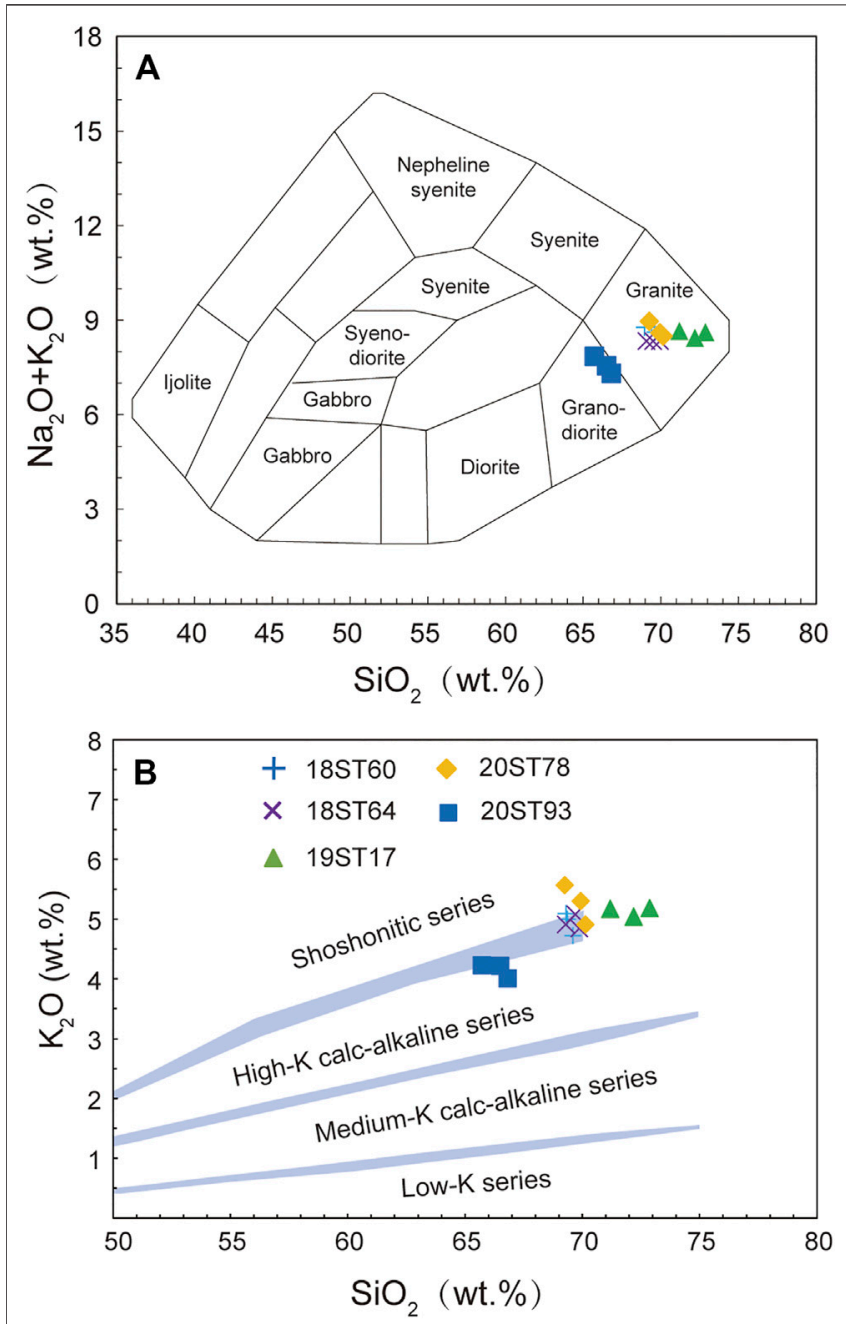

FIGURE 7 | Petrochemical classification diagrams of the Permian granitoids, and their characteristic major elements. (A) Total alkalis vs. silica diagram (after Cox et al., 1979) showing that the samples plot in the fields of granite and granodiorite, which is consistent with their main mineral compositions shown in Figure 3; (B) $\mathrm{K}_{2} \mathrm{O}(\%)$ vs. $\mathrm{SiO}_{2}$ (\%) diagram (after Peccerillo and Taylor, 1976) showing that the investigated granitoids belong to the high calc-alkaline to shoshonitic series.

et al., 1979). This sample is also characterized by relatively higher concentrations of $\quad \mathrm{Al}_{2} \mathrm{O}_{3} \quad\left(15.42-15.56\right.$ wt.\%), $\quad \mathrm{TiO}_{2}$ (0.63-0.66 wt.\%), $\mathrm{CaO}$ (2.18-2.65 wt.\%), $\mathrm{MgO}$ (1.51-1.55 wt.\%) and $\mathrm{P}_{2} \mathrm{O}_{5}(0.27-0.30$ wt.\%).

Based on the $\mathrm{K}_{2} \mathrm{O}$ (wt.\%) vs. $\mathrm{SiO}_{2}$ (wt.\%) diagram (Figure 7B) (Peccerillo and Taylor, 1976), the studied samples plot in the fields of the high-K calc-alkaline and shoshonitic series, with high $\mathrm{K}_{2} \mathrm{O}$ content ranging from 4.01 to 5.69 wt.\% and $\mathrm{K}_{2} \mathrm{O} / \mathrm{Na}_{2} \mathrm{O}$ ratios from 1.17 to 1.64 (Supplementary Table S4). All samples are metaluminous and/or slightly peraluminous granitoids as indicated by their $\mathrm{A} / \mathrm{CNK}$ ratios $(0.95-1.10)$, and mostly they plot on the left side of the I-S line $(\mathrm{A} / \mathrm{CNK}=1.1)$ in the $\mathrm{A} / \mathrm{NK}$ vs. A/CNK diagram (Figure 8) (Maniar and Piccoli, 1989).

One of the common features of the Permian granitoids is their significant negative $\mathrm{Nb}$ and $\mathrm{Ta}$ anomalies in the primitive 


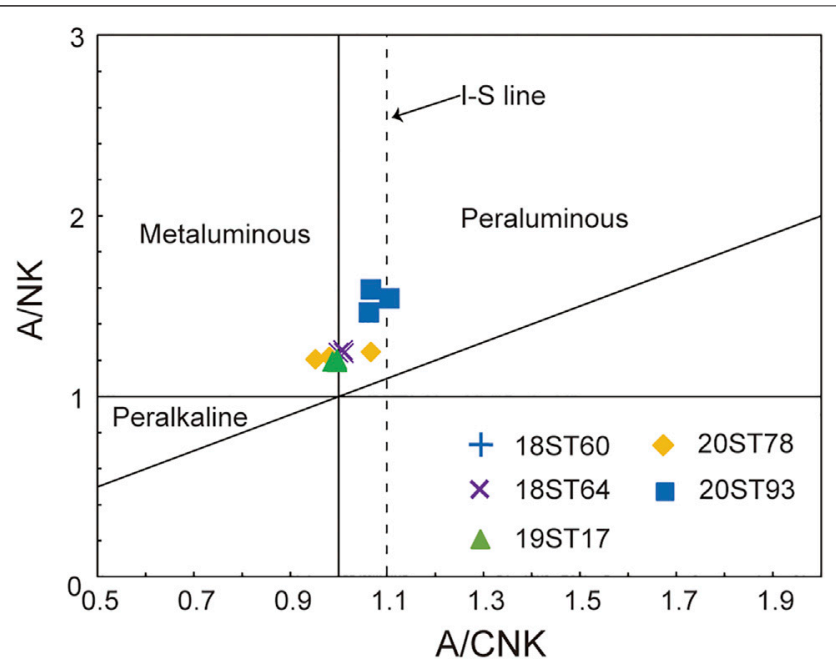

FIGURE 8 | Plot of $\mathrm{A} / \mathrm{NK}\left(\mathrm{Al}_{2} \mathrm{O}_{3} / \mathrm{Na}_{2} \mathrm{O}+\mathrm{K}_{2} \mathrm{O}\right)$ molar vs. $\mathrm{A} / \mathrm{CNK}\left(\mathrm{Al}_{2} \mathrm{O}_{3}\right)$ $\mathrm{CaO}+\mathrm{Na}_{2} \mathrm{O}+\mathrm{K}_{2} \mathrm{O}$ ) molar (after Maniar and Piccoli, 1989) showing the slightly peraluminous to metaluminous nature of the studied Permian granitoids.

mantle-normalized spider diagrams (Figure 9A) (Sun and McDonough, 1989), which are also characterized by conspicuous enrichments of some LILEs such as $\mathrm{Rb}$, Th, $\mathrm{U}$, and evident depletion of $\mathrm{Ba}$ and $\mathrm{Sr}$.

The Permian granitoids have similar chondritenormalized rare earth element (REE) patterns as indicated by their significant enrichments in light rare earth elements (LREEs) relative to heavy rare earth element (HREE) with $(\mathrm{La} / \mathrm{Yb})_{\mathrm{N}}$ values between 7.8 and 37.9 (Figure 9B; Supplementary Table S4). All samples demonstrate a significant fractionated REE pattern indicated by high (La/ $\mathrm{Sm})_{\mathrm{N}}$ values between 3.3 and 5.2. Except for sample $20 \mathrm{ST} 93$ (0.73-0.79), the remaining five samples show distinct negative Eu anomalies (0.26-0.52) with a concave-upward shape (Figure 9B).

\section{DISCUSSION}

\subsection{Genetic Classification of the Permian Granitoids}

All the studied granitoids generally show high contents of $\mathrm{K}_{2} \mathrm{O}+$ $\mathrm{Na}_{2} \mathrm{O}$ (7.31-9.36 wt.\%) and high field strength elements (HFSE; $\mathrm{Zr}+\mathrm{Nb}+\mathrm{Ce}+\mathrm{Y}=365-802 \mathrm{ppm})$ with relatively lower concentrations of $\mathrm{CaO} \quad(0.22-1.70$ wt.\%) and $\mathrm{MgO}$ (0.12-0.48 wt.\%) and the primitive mantle-normalized spider diagrams have well defined negative anomalies of $\mathrm{Ba}$ and $\mathrm{Sr}$ (Figure 9A). These geochemical characteristics demonstrate that rocks have an A-type granite affinity (Eby, 1992; Whalen et al., 1987). Additionally, the samples are characterized by high $\mathrm{Ga} / \mathrm{Al}$ ratios (2.8-4.2), which have been identified as a useful parameter to discriminate A-type granites (Whalen et al., 1987). As shown in Figure 10, these granitoids plot within the A-type granite field in the $\mathrm{Zr}$ vs. $10000 \times \mathrm{Ga} / \mathrm{Al},\left(\mathrm{K}_{2} \mathrm{O}+\mathrm{Na}_{2} \mathrm{O}\right) / \mathrm{CaO}$ vs. $(\mathrm{Zr}+\mathrm{Nb}+\mathrm{Ce}+$ $\mathrm{Y}),(\mathrm{Zr}+\mathrm{Nb}+\mathrm{Ce}+\mathrm{Y})$ vs. $10000 \times \mathrm{Ga} / \mathrm{Al}$ and $\mathrm{Nb}$ vs. $10000 \times \mathrm{Ga} /$
Al diagrams (Whalen et al., 1987). They also plot in the A-type granite field in the whole-rock $\mathrm{CaO} /\left(\mathrm{FeO}^{\mathrm{t}}+\mathrm{MgO}+\mathrm{TiO}_{2}\right)$ vs. $\mathrm{CaO}+\mathrm{Al}_{2} \mathrm{O}_{3}$ and $\mathrm{CaO} /\left(\mathrm{FeO}^{\mathrm{t}}+\mathrm{MgO}+\mathrm{TiO}_{2}\right)$ vs. $\mathrm{Al}_{2} \mathrm{O}_{3}$ diagrams (Figure 11) (Dall'Agnol and de Oliveira, 2007).

The A-type affinity of the Permian granitoids is further demonstrated by their relatively high melting temperature $\left(824-875^{\circ} \mathrm{C}\right)$ based on the $\mathrm{Zr}$ saturation in the magma system (Watson and Harrison, 1983). This temperature is consistent with that of typical A-type granites, but it is much higher than that of I-type granites $\left(781{ }^{\circ} \mathrm{C}\right.$ and $764{ }^{\circ} \mathrm{C}$ for unfractionated and fractionated I-type granites, respectively) (King et al., 1997). Moreover, all samples are characterized by high $\mathrm{Zr} / \mathrm{Hf}$ ratios (35-43), indicating they are moderately fractionated compared with highly fractionated granitoids (Wu et al., 2017). Therefore,
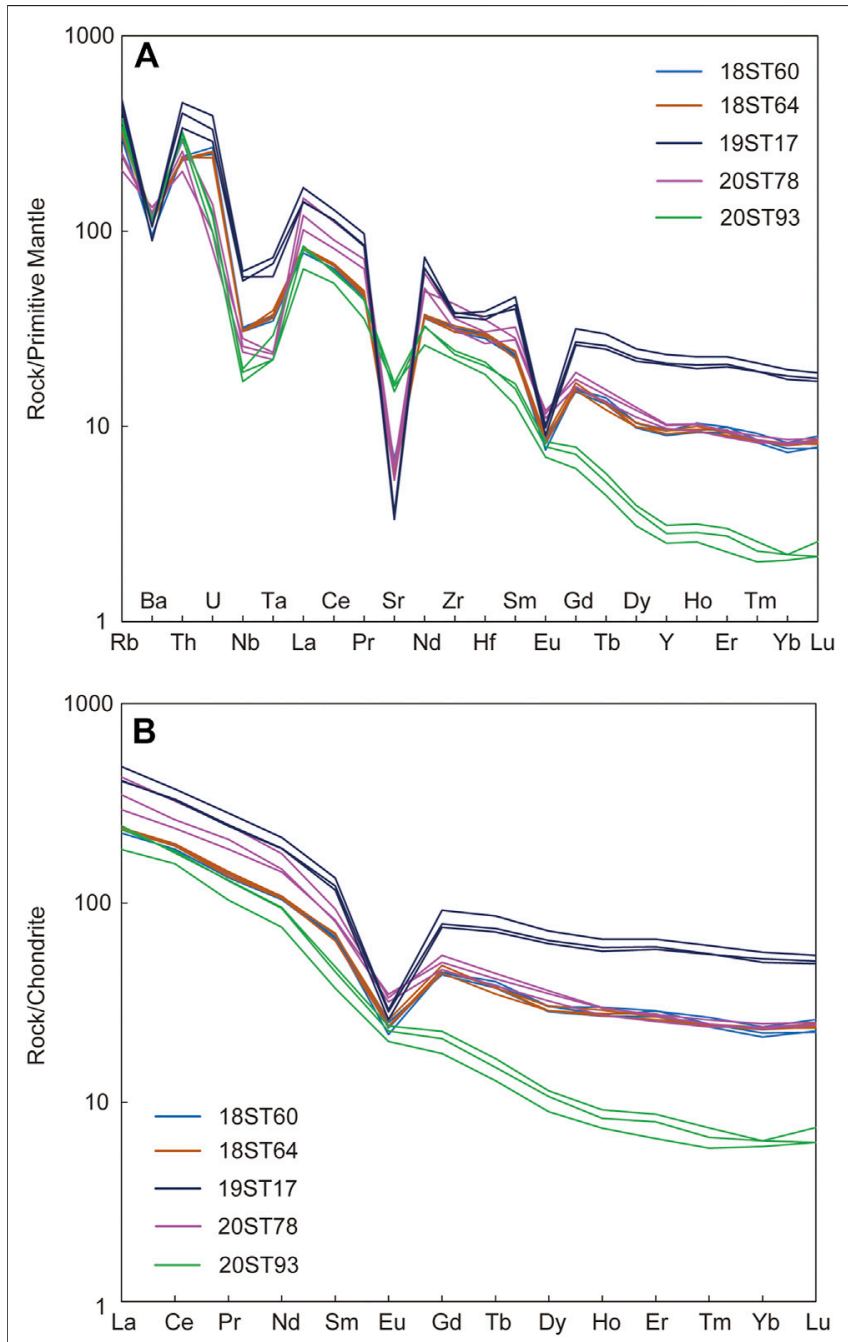

FIGURE 9 | (A) Primitive mantle-normalized multi-element distributions showing the significant negative $\mathrm{Nb}$ and Ta anomalies, and conspicuous enrichments of LILEs such as Rb, Th, U; (B) Chondrite-normalized REE patterns showing the evident enrichments in light rare earth elements (LREEs) relative to heavy rare earth element (HREE), which all point to subduction-related trace element signatures. Chondrite and primitive mantle values are after Sun and McDonough (1989). 

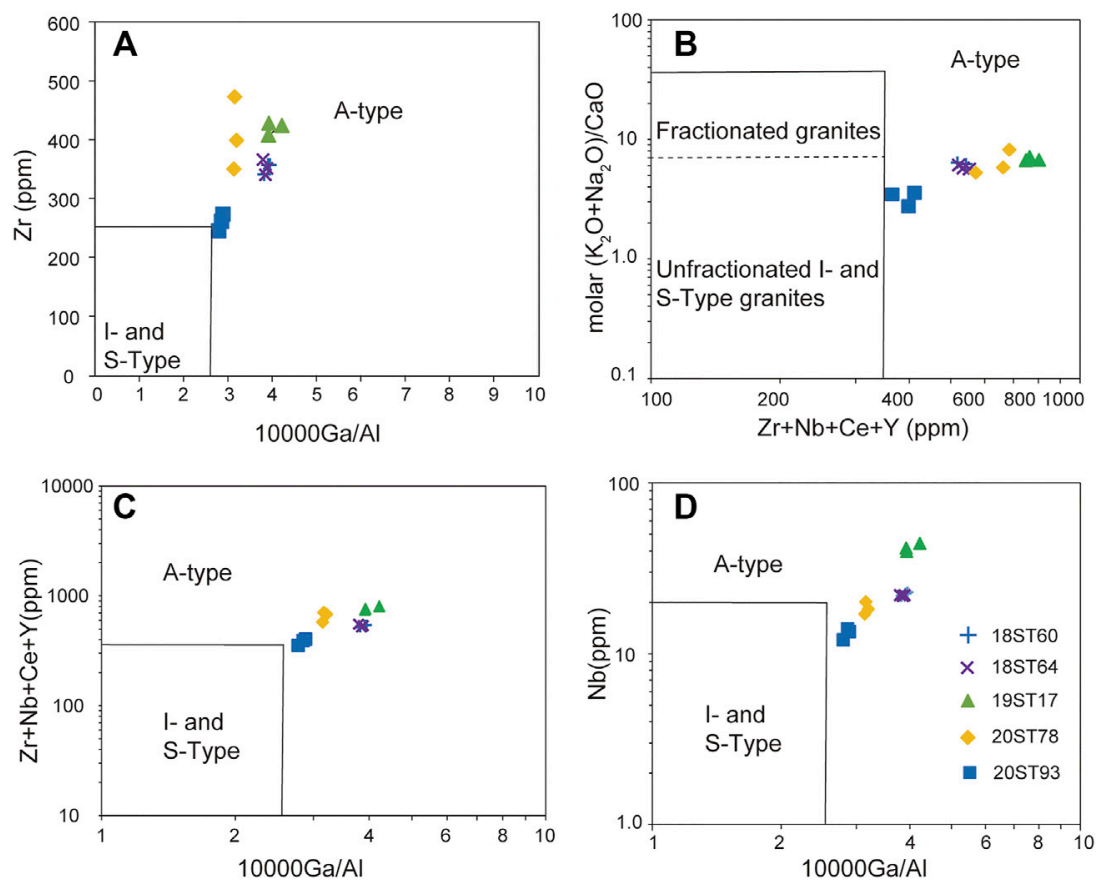

FIGURE 10 | Genetic discrimination diagrams (after Whalen et al., 1987) showing the A-type affinity of the Permian granitoids in this study. (A) Zr vs. $10000 \times$ Ga/Al diagram; (B) $\left(\mathrm{K}_{2} \mathrm{O}+\mathrm{Na}_{2} \mathrm{O}\right) / \mathrm{CaO}$ vs. $(\mathrm{Zr}+\mathrm{Nb}+\mathrm{Ce}+\mathrm{Y})$ diagram (C) $(\mathrm{Zr}+\mathrm{Nb}+\mathrm{Ce}+\mathrm{Y})$ vs. $10000 \times \mathrm{Ga} / \mathrm{Al}$ diagram (D) Nb vs. $10000 \times \mathrm{Ga} / \mathrm{Al}$ diagram.
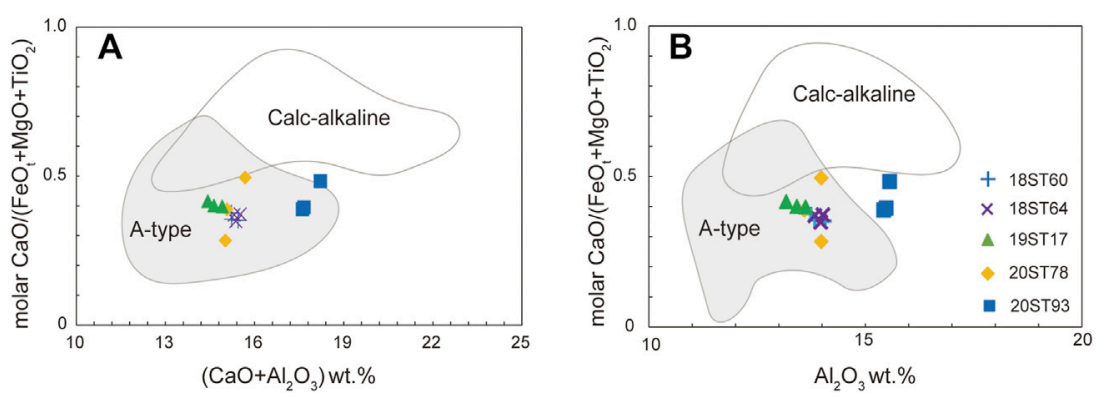

FIGURE 11 | Whole-rock $\mathrm{CaO} /\left(\mathrm{FeO}^{\mathrm{t}}+\mathrm{MgO}+\mathrm{TiO}_{2}\right)$ vs. $\mathrm{CaO}+\mathrm{Al}_{2} \mathrm{O}_{3}$ (A) and $\mathrm{CaO} /\left(\mathrm{FeO}{ }^{\mathrm{t}}+\mathrm{MgO}+\mathrm{TiO}_{2}\right)$ vs. $\mathrm{Al}_{2} \mathrm{O}_{3}$ (B) diagrams $($ after Dall'Agnol and de Oliveira, 2007) showing the A-type affinity of the studied Permian granitoids.

we consider that the Permian granitoids in this study are A-type granites.

\subsection{Petrogenesis and Geodynamic Setting}

As noted earlier, there is currently no consensus regarding the petrogenesis and geodynamic setting responsible for the Permian granitoids in the South Tianshan. This section integrates all available regional geological, geochronological and geochemical data in order to evaluate the existing controversies, after which we propose an alternative geodynamic scenario to explain the generation of the Permian granitoids.

\subsubsection{Genetically Related to the Tarim Mantle Plume?}

One major interpretation is that the Permian granitoids in the South Tianshan are genetically related to the mantle plume in the
Tarim Craton (e.g., Zhang and Zou, 2013); this model is mainly based on the coincidence in time of the plume compared with that of the putative plume-induced A-type granites (Su et al., 2019; Wei et al., 2019). However, there are significant differences in the characteristics of the A-type granites in the two areas as follows:

Firstly, the Permian A-type granites in the western Tarim Craton are spatially and temporally closely associated with voluminous plume-derived basalts, mafic-ultramafic intrusive complexes and abundant alkali mafic dykes (Zou et al., 2015). In contrast, in the South Tianshan the Permian magmatism lacks these hallmarks and instead is dominated by felsic intrusions. Furthermore, the well documented A-type granitoids in the South Tianshan (Huang et al., 2015a; Konopelko et al., 2007, 2009; Long et al., 2008; Wang et al., 2007b) mostly have an $\mathrm{A}_{2}$-subtype affinity based on the ternary discrimination diagrams 


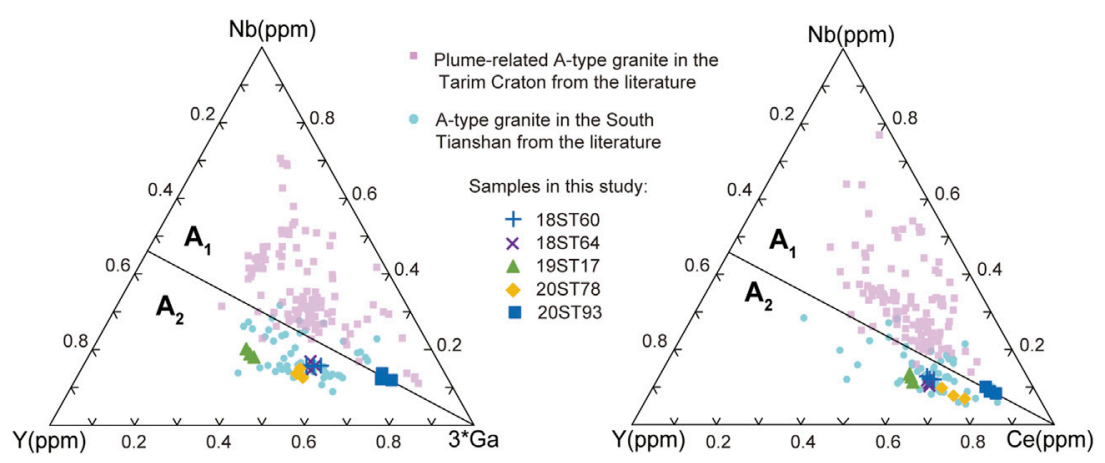

FIGURE 12 | Discrimination diagrams (after Eby, 1992) showing the dominant $A_{2}$-subtype affinity of the A-type granitoids in the South Tianshan (literature data sources: Konopelko et al., 2007, 2009; Huang et al., 2015a; Long et al., 2008; Wang et al., 2007b), which is significantly different from the plume-related A,-subtype affinity of the granites in the Tarim craton (data sources: Huang et al., 2012; Su et al., 2019; Wei et al., 2019; Wei and Xu, 2011; Yang et al., 2007; Zhang et al., 2008).

(Figure 12), and that is significantly different from the plumeinduced $\mathrm{A}_{1}$-subtype granites in the Tarim Craton (Yang et al., 2007; Zhang et al., 2008; Wei and Xu, 2011; Huang et al., 2012; Su et al., 2019; Wei et al., 2019).

Secondly, the A-type granites in the South Tianshan have distinctive negative $\mathrm{Nb}$ and $\mathrm{Ta}$ anomalies (Figure 9A), which are commonly indicative of a subduction-influenced origin, whereas those in the western Tarim have apparent positive $\mathrm{Nb}$ and $\mathrm{Ta}$ anomalies (Figure 3, Wei et al., 2019; Figure 7, Zhang and Zou, 2013; Figure 8B, Zou et al., 2015).

Thirdly, there is a general Hf isotopic difference between the plume-related A-type granites of Tarim and those in the South Tianshan. This not only demonstrates the distinctive $\mathrm{Hf}$ compositions of the studied granitoids, but also highlights the contrasting difference in their magma sources. As shown in Figures 5, 6, the A-type granites in the western Tarim are characterized by distinctive positive $\varepsilon_{\mathrm{Hf}}(\mathrm{t})$ values and corresponding younger crustal model ages (Zou et al., 2015). The relatively depleted feature of the A-type granites in the Tarim Craton is interpreted to result from intensive fractionation of a plume-related OIB-like basaltic magma (Zou et al., 2015), or from partial melting of newly underplated rocks induced by the mantle plume, followed by extensive fractionation and minor crustal assimilation (Su et al., 2019). In contrast, the A-type granitoids in the South Tianshan display apparently negative to slightly positive $\varepsilon_{\mathrm{Hf}}(\mathrm{t})$ values $(-10.9$ to +0.6$)$ and older crustal model ages (1727-1759 Ma), as compared with those in the western Tarim. This is consistent with the $\mathrm{Nd}$ isotope compositions $\left(\varepsilon_{\mathrm{Nd}}(\mathrm{t})=-1.6\right.$ to-6.9) of the A-type granites from Kyrgyzstan (Konopelko et al., 2007), indicating their derivation from very different magma sources (section 6.2.3). The molar oxide discrimination diagram of $\mathrm{CaO} /\left(\mathrm{MgO}+\mathrm{FeO}^{\mathrm{t}}\right)$ vs. $\mathrm{Al}_{2} \mathrm{O}_{3} /$ $\left(\mathrm{MgO}+\mathrm{FeO}^{\mathrm{t}}\right)$ (Altherr et al., 2000) indicates that they were mainly generated by partial melting of meta-greywackes (Figure 13), suggesting an arc-related tectonic setting (Yin et al., 2021), which is in accordance with the deep $\mathrm{Nb}$ and $\mathrm{Ta}$ troughs reflected by the multi-element spider diagram for the granitoids (Figure 9A).

Last but not least, the difference is also shown by the lower zircon saturation temperatures $\left(824-875^{\circ} \mathrm{C}\right)$ of the A-type

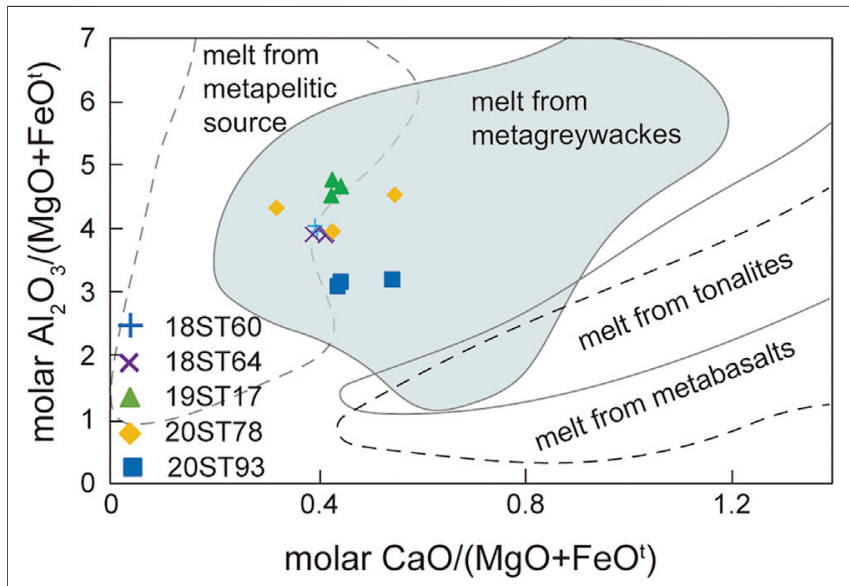

FIGURE 13 $\mid$ Binary plot $\mathrm{CaO} /\left(\mathrm{MgO}+\mathrm{FeO}^{t}\right)$ vs. $\mathrm{Al}_{2} \mathrm{O}_{3} /\left(\mathrm{MgO}+\mathrm{FeO}^{t}\right)(\mathrm{mol}$ \%) (after Altherr et al., 2000) showing that the Permian granitic magma was mainly generated by the melting of meta-greywackes composed of arcrelated volcanogenic sedimentary rocks.

granites in the South Tianshan, as compared with those in the western Tarim $\left(890-1,010^{\circ} \mathrm{C}\right.$ ) (Su et al., 2019), which likely suggests the magmas were generated by fundamentally different crustal melting processes.

The above significant observations demonstrate the notable differences between the A-type granites in these two tectonic environments from which it is evidence that the geodynamic process for generation of the A-type granites in the South Tianshan was different from that responsible for those in the Tarim Craton (Wei et al., 2019). This reasoning is supported (Xiao et al., 2013; Abuduxun et al., 2021a) by the fact that the South Tianshan was still separated from the Tarim Craton in the Early Permian when the mantle plume was active. Consequently, we conclude that it is unlikely that the Tarim mantle plume was responsible for the A-type magmatism in the South Tianshan.

\subsubsection{Products of Post-collisional Magmatism?}

A second common interpretation for the petrogenesis of the Permian granitoids in the South Tianshan is that they formed in a 
post-collisional setting (Wang et al., 2007b; Konopelko et al., 2007, 2009; Ma et al., 2015; Qin et al., 2021). This interpretation is mainly based on the following two preconditions:

1) The Atbashi-Inylchek-South Nalati Fault was the terminal suture between the Yili-Central Tianshan arc and the Tarim Craton (e.g., Wang et al., 2018b), and consequently the South Tianshan was a passive margin of the northern Tarim Craton (Gao et al., 1998; Biske et al., 2018). That idea leads to the conclusion that the Early Permian granitoids penetrated simultaneously both upper (active) and lower (passive) plates of the orogen, and therefore they formed across the suture in post-collisional times (e.g., Han et al., 2011; Ma et al., 2015).

2) Northward subduction of the South Tianshan oceanic lithosphere stopped before the Early Permian (Han et al., 2016; Huang et al., 2018; Alexeiev et al., 2019).

Given the widespread occurrence of geologically and structurally well investigated OPS mélanges, ophiolites and imbricated trench-filled turbidites, the South Tianshan orogen was considered to be an accretionary complex that formed on the southern active margin of the Yili-Central Tiranshan arc by continuous northward subduction of the South Tianshan oceanic lithosphere (Xiao et al., 2013; Sang et al., 2018; Abuduxun et al., 2021b). A further line of geochronological evidence indicates that the closure of the South Tianshan Ocean lasted to the End-Permian to Late Triassic ( $\mathrm{Li}$ et al., 2005; Sang et al., 2017; Wen et al., 2020; Abuduxun et al., 2021a). That is to say, the South Tianshan was on the leading edge of the upper plate (the Yili-Central Tianshan arc), and was separated from the Keping passive margin by a wide ocean until the Late Permian to Late Triassic when the terminal suture formed along the base of the accretionary complex (Xiao et al., 2013; Abuduxun et al., 2021a). Accordingly, it is apparent that the Permian granitoids in the South Tianshan formed in the upper plate, rather than in the lower plate, because the terminal suture between the Yili-Central Tianshan arc and the Tarim Craton is roughly along the North Tarim Fault to the south (Xiao et al., 2013; Abuduxun et al., 2021a), and not along the AtbashiInylchek-South Nalati Fault to the north (e.g., Wang et al., 2018b).

Critically, as discussed in section 6.2.1, the Permian A-type granites in the Keping area, where the leading edge of the lower plate was located, were genetically related to a mantle plume, and bear no resemblance in either rock associations or elemental and isotopic geochemistry to those in the South Tianshan. The key implication from the above reasoning is that it is unlikely that the Permian plutons in the South Tianshan formed across the terminal suture, as previously considered (e.g., Han et al., 2011; Wang et al., 2018a), but rather that they were confined to the upper plate beneath which north-dipping subduction of the oceanic lithosphere was still active. Thus, the post-collision model is implausible.

\subsubsection{An Alternative Petrogenetic-Tectonic Model}

As demonstrated in section 6.1, a result of the genetic classification based on major and trace element geochemistry, integrated with high melting temperatures $\left(824-875^{\circ} \mathrm{C}\right)$, is that the Permian granitoids in the South Tianshan have an A-type affinity.

There has long been a general consensus that A-type granites mostly formed in extensional tectonic environments regardless of the source of their magmas (Whalen et al., 1987; Wu et al., 2017).

All our studied samples belong to the $A_{2}$-subtype (Figure 12), which is widely considered to be associated with extension events in convergent margins (Eby, 1992). Nevertheless, a distinctive feature of our Permian A-type granitoids is that they have diagnostic subduction-related trace element signatures such as deep $\mathrm{Nb}$ and Ta troughs (Figure 9A), elevated LILEs and flat HFSEs patterns (Figure 9B), all very similar to those of granites in the Lachlan accretionary orogen in Australia, which robust analysis has convincingly demonstrated to have formed in a subductiongenerated arc (e.g., Collins et al., 2019). Accordingly, we integrated our new results with published, high-quality, comprehensive, sedimentological, structural and geochronological data (Xiao et al., 2013; Sang et al., 2018; Abuduxun et al., 2021a), which conformed that the Permian A-type granitoids in the South Tianshan formed in an extensional supra-subduction setting. Corroborative evidence for such extension comes from the presence of Early Permian extensional faulted basins in the South Tianshan (Liu et al., 2013) and the ca. $272 \mathrm{Ma}$ high-temperature granulite facies metamorphism in the Yushugou area (Zhang et al., 2019b). Apatite fission track (AFT) thermochronology results have also suggested that the southwestern Tianshan had no strong uplifting in the Permian (Dumitru et al., 2001).

In addition, of the 299-282 Ma rhyolitic and basaltic lavas from the Xiaotikanlike Formation in the Heiyingshan section of the South Tianshan (Liu et al., 2014), the basaltic lavas have trace and rare element patterns similar to those of oceanic island basalts (Huang et al., 2015b), and the rhyolites have relatively high $\mathrm{Zr}$ saturation temperatures (up to $824^{\circ} \mathrm{C}$ ), which can be most likely attributed to an increased heat input from underplated mantlederived basaltic magmas (Cheng et al., 2017). Therefore, these volcanic rocks are consistent with and indeed point to formation in an Early Permian extensional setting in the South Tianshan.

A similar Early Permian extensional situation is also reported from the Yili-Central Tianshan. The geological structure profile based on seismic data in the Zhaosu-Tekesi Depression shows that the Lower Permian strata are characterized by titled rotation downward near the NE-trending normal fault, indicating a sedimentary filling pattern of the extensional faulted (or rifted) basin and related thermal subsidence in the southern Yili Block (Li D. et al., 2015). The Early Permian A-type granites in the YiliCentral Tianshan (Xu et al., 2013; Li N.-B. et al., 2015) also require an extensional environment for the high-temperature magmatism.

Taking into consideration the fact that formation of these Permian granitoids was structurally confined to a narrow linear belt along the strike of the orogen (Figure 1B), we consider that the subduction-related extension was most likely triggered by slab rollback, which usually causes major contemporaneous thermal anomalies along the strike of a subduction zone. Again, we emphasize that neither the Tarim mantle plume model nor the post-collisional extension model can explain the arc-parallel linear distribution of the Permian granitoids. 


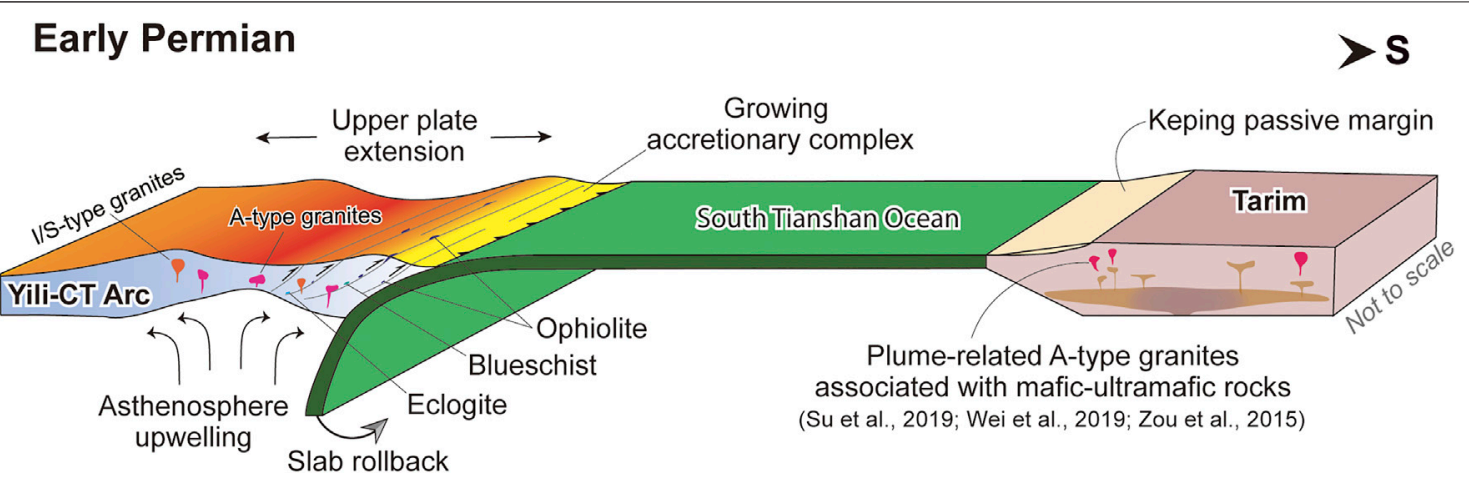

FIGURE 14 | Schematic model illustrating the tectonic relations that were responsible for the Early Permian A-type granitoids in the South Tianshan. In the Early Permian, upper plate extension was probably related to southward slab rollback that induced upwelling of asthenospheric mantle, which led to large-scale crustal melting that gave rise to the broad granitic arc in the southern active margin of the Yili-Central Tianshan. Formation of the A-type granitoids was facilitated by the high heat gradient beneath the extensional upper plate.

Given the evidence presented above, we propose a new petrogenetic-tectonic model as visualized in Figure 14. The southward rollback of the northward subducting South Tianshan oceanic lithosphere triggered extension in the overring plate and associated upwelling of asthenospheric mantle in the Early Permian. The southward slab rollback consequently provided a suitable condition for magma underplating combined with increased temperature leading to large-scale crustal melting, which gave rise to a broad, linear belt of arc magmatism in the southern active margin of the YiliCentral Tianshan (Figure 1B) where the A-type granitoids were produced as a result of the high thermal gradient.

The A-type granites have slightly enriched $\mathrm{Hf}$ isotopic compositions (Figure 5; $\varepsilon_{\mathrm{Hf}}(\mathrm{t})=-10.9$ to +0.6 ), indicating that neither mantle nor juvenile crustal material could be major contributors to their magma generation. On the other hand, this implies that the corresponding older crustal model ages, mainly concentrated at 1,272-1759 Ma, were generated by remelting of Mesoproterozoic recycled crustal components, and those samples that plot in the meta-greywacke field in the molar oxide discrimination diagram (Figure 13) were no doubt mainly derived by partial melting of arc-related volcanogenic sedimentary rocks (Yin et al., 2021). Therefore, mature crustal material with minor mantle-derived magmatic inputs were the most feasible magma source for the investigated A-type granites.

In summary, subduction-related extension triggered by slab rollback was the most likely tectonic environment for generation of the A-type granitoids in the South Tianshan. The ambient processes predictably involved the upwelling of asthenosphere, decompression melting, and an associated rise in temperature, which all led to large-scale partial melting in the upper plate.

\subsection{Implications for the Retreating Accretionary Orogenesis of the Southern Altaids}

A specific comparison of the rock associations, $\mathrm{Lu}-\mathrm{Hf}$ isotopic compositions, whole-rock geochemistry, and magma conditions highlights the contrasting differences between the A-type granites in the South Tianshan and those in the western Tarim Craton. Consequently, it is unlikely they were involved in the same geodynamic process. That is to say, the South Tianshan was not affected by the Permian Tarim mantle plume. This is supported by provenance analysis, which provided no evidence for the presence of voluminous plume-related detritus in the Permian-lower Triassic strata from the South Tianshan (Liu et al., 2013; Abuduxun et al., 2021a). Therefore, a robust analysis of all variable factors leads to the conclusion that the South Tianshan and the Tarim Craton was still separated by a wide ocean in the Permian, and accordingly this negates any idea of pre-Permian closure of the South Tianshan ocean (Han et al., 2011; Wang et al., 2018b; Alexeiev et al., 2019). Therefore, it is reasonable to suggest that the South Tianshan was unlikely a plume-modified collisional orogeny (Han et al., 2019).

A significant Late Carboniferous magmatic "flare-up"event has been well documented in the Yili-Central Tianshan arc, which is characterized by coeval mafic and felsic magmatic rocks, such as ca. 337-322 Ma bimodal volcanic rocks in the Wusun mountain (Su et al., 2021), ca. 317-310 Ma mafic dikegranitoid associations in the Zhongyangchang area (Tang et al., 2014), and ca. $314 \mathrm{Ma}$ adakitic granodiorites in the Qiongkusitai area (Yin et al., 2016). Geochemically, they show a clear arcaffinity; moreover, the mafic rocks were likely derived from a depleted mantle source containing an asthenospheric component (Tang et al., 2014). Therefore, the magmatic "flare-up"has been interpreted to be formed in a subduction-related extensional setting triggered by southward rollback of the South Tianshan oceanic lithosphere (e.g., Tang et al., 2014; Yin et al., 2016). If integrated with the Permian A-type granitoids in the South Tianshan, these extension-related magmatic rocks show a trend of southward migration. This observation is also supported by the southward growth of the South Tianshan accretionary complex as indicated by the oceanward younging of the maximum depositional ages of trench-filled turbidites (Abuduxun et al., 2021a, b; Fu et al., 2018). Therefore, it is reasonable to propose that the Late Carboniferous-Early Permian broad magmatic arc with diverse extension-related 
magmatism that requires a high temperature in the southern active margin of the Yili-Central Tianshan was built probably as a result of prolonged southward rollback of the progressively aging South Tianshan oceanic lithosphere before its final closure in the End-Permian to Late Triassic (Xiao et al., 2013; Sang et al., 2018; Wen et al., 2020; Abuduxun et al., 2021a), and that led to the final amalgamation of the Yili-Central Tianshan arc with the Tarim Craton (Gao et al., 2011; Han et al., 2011; Xiao et al., 2015).

The newly identified Permian A-type granites in this study share the same geochemical and isotopic characteristics with widespread coeval A-type granites in Kyrgyz South Tianshan (Konopelko et al., 2007, 2009). Therefore, the retreating and extensional accretionary structure of the southern Altaids is well recorded by the linear distributed and spatiotemporal-orientated Late Carboniferous-Early Permian magmatic "flare-up" along the southern active margin of the Yili-Central Tianshan from Kyrgyzstan to NW China.

\section{CONCLUDING REMARKS}

LA-ICP-MS zircon U-Pb dating reveals that the newly identified A-type granitoids from the South Tianshan in the southern Altaids were emplaced at ca. 298-272 Ma. The whole-rock geochemistry and calculated zircon saturation temperatures indicate that these are metaluminous to slightly peraluminous $\mathrm{A}_{2}$-type granites. The zircon $\mathrm{Hf}$ isotopic compositions show that the granitoids were mainly generated by partial melting of mature crustal components with a minor contribution from a mantlederived magmatic source.

The A-type granitoids in the South Tianshan are incontrovertibly different from those in the western Tarim Craton in terms of mantle plume generation. Integration of the new and previous data leads to the conclusion that they were produced due to a high temperature gradient in an extensional, subduction-generated environment probably induced by southward slab rollback of the South Tianshan oceanic lithosphere, rather than due to post-collisional extension.

In the Permian the South Tianshan in the southern Altaids was a retreating extensional accretionary orogen rather than a plumemodified collisional orogen.

\section{REFERENCES}

Abuduxun, N., Windley, B. F., Xiao, W. J., Zhang, J. E., Chen, Y. C., and Huang, P. (2021b). Carboniferous Tectonic Incorporation of a Devonian Seamount and Oceanic Crust into the South Tianshan Accretionary Orogen in the Southern Altaids. Int. J. Earth Sci. 1, 1. doi:10.1007/s00531-021-02109-6

Abuduxun, N., Xiao, W. J., Windley, B. F., Chen, Y. C., Huang, P., and Sang, M.et al (2021a). Terminal Suturing between the Tarim Craton and the Yili-Central Tianshan Arc: Insights from Mélange-Ocean Plate Stratigraphy, Detrital Zircon Ages and Provenance of the South Tianshan Accretionary Complex. Tectonics 40, e2021TC006705. doi:10.1029/2021TC006705

Alekseev, D. V., Degtyarev, K. E., Kotov, A. B., Sal'nikova, E. B., Yakovleva, S. Z., and Shatagin, K. N. (2009). Late Paleozoic Subductional and Collisional Igneous

\section{DATA AVAILABILITY STATEMENT}

The original contributions presented in the study are included in the article/Supplementary Material, further inquiries can be directed to the corresponding author.

\section{AUTHOR CONTRIBUTIONS}

NA provided initial data. WX designed the study. BW corrected and improved the writing of the manuscript. NA, PH, JG conducted the fieldwork. HY participated in analysis on petrology and photomicrographs. MS helped with the LACIP-MS zircon U-Pb dating. XL helped with the Hf isotopic analysis. All authors participated in discussion of the study and approved the submitted version.

\section{FUNDING}

This study was financially supported by funds from the National Natural Science Foundation of China (41888101, 41962013, 42072269), the National Key R \& D Program of China (2017YFC0601206), the Key Research Program of Frontier Sciences of the CAS (QYZDJ-SSW-SYS012), the "Light of West China" Program of the CAS (2018-XBYJRC-003), and CAS Project of the China-Pakistan Joint Research Center on Earth Sciences (131551KYSB20200021).

\section{ACKNOWLEDGMENTS}

Careful reviews and insightful suggestions from the reviewers greatly improved the manuscript. Editorial handling by Dr. Xiubin Lin is highly appreciated.

\section{SUPPLEMENTARY MATERIAL}

The Supplementary Material for this article can be found online at: https://www.frontiersin.org/articles/10.3389/feart.2021.831677/ full\#supplementary-material

Complexes in the Naryn Segment of the Middle Tien Shan (Kyrgyzstan). Dokl. Earth Sc. 427, 760-763. doi:10.1134/s1028334x09050122

Alexeiev, D. V., Biske, Y. S., Djenchuraeva, A. V., Kröner, A., and Getman, O. F. (2019). Late Carboniferous (Kasimovian) Closure of the South Tianshan Ocean: No Triassic Subduction. J. Asian Earth Sci. 173, 54-60. doi:10.1016/ j.jseaes.2019.01.021

Alexeiev, D. V., Biske, Y. S., Wang, B., Djenchuraeva, A. V., Getman, O. F., Aristov, V. A., et al. (2015). Tectono-Stratigraphic Framework and Palaeozoic Evolution of the Chinese South Tianshan. Geotecton. 49, 93-122. doi:10.1134/ S0016852115020028

Altherr, R., Holl, A., Hegner, E., Langer, C., and Kreuzer, H. (2000). Highpotassium, Calc-Alkaline I-type Plutonism in the European Variscides: Northern Vosges (France) and Northern Schwarzwald (Germany). Lithos 50, 51-73. doi:10.1016/s0024-4937(99)00052-3 
BGMRXUAR (1982). Introduction of Geological Map of the Hantenggeli and Quexiang areasXinjiang Bereau of Geology and Mineral Resources (In Chinese). pp.107. Map scale at 1, 200000.

BGMRXUAR (1975a). Introduction of Geological Map of the Kule Area200000, Xinjiang Bereau of Geology and Mineral Resources (In Chinese). Map scale at 1, 40.

BGMRXUAR (1965). Introduction of Geological Map of the Lake Baghrash Area200000, Xinjiang Bereau of Geology and Mineral Resources (In Chinese). Map scale at 1, 42.

BGMRXUAR (1975b). Introduction of Geological Map of the Yanqi Area200000, Xinjiang Bereau of Geology and Mineral Resources (In Chinese). Map scale at $1,37$.

BGMRXUAR (1993), Regional Geology of Xinjiang Uygur Autonomous Region, Geological Publishing House, Beijing (in Chinese with English abstract). pp.841.

Biske, Y. S., Alexeiev, D. V., Djenchuraeva, A. V., Wang, B., Getman, O. F., and Liu, H. S. (2018). Continuous Sections of the Devonian and Carboniferous Carbonates and Timing of Collision in the Chinese South Tianshan. Dokl. Earth Sc. 481, 842-846. doi:10.1134/S1028334X18070024

Blichert-Toft, J., Chauvel, C., and Albarède, F. (1997). Separation of Hf and Lu for High-Precision Isotope Analysis of Rock Samples by Magnetic Sector-Multiple Collector ICP-MS. Contrib. Mineralogy Petrology 127, 248-260. doi:10.1007/ s004100050278

Bouvier, A., Vervoort, J. D., and Patchett, P. J. (2008). The Lu-Hf and Sm-Nd Isotopic Composition of CHUR: Constraints from Unequilibrated Chondrites and Implications for the Bulk Composition of Terrestrial Planets. Earth Planet. Sci. Lett. 273, 48-57. doi:10.1016/j.epsl.2008.06.010

Cheng, Z., Zhang, Z., Santosh, M., Zhao, Z., and Chen, L. (2017). Late Carboniferous to Early Permian Partial Melting of the Metasedimentary Rocks and Crustal Reworking in the Central Asian Orogenic Belt: Evidence from Garnet-Bearing Rhyolites in the Chinese South Tianshan. Lithos 282-283, 373-387. doi:10.1016/j.lithos.2017.03.017

Collins, W. J., Huang, H. Q., Bowden, P., and Kemp, A. I. S. (2019). Repeated S-I-Atype Granite Trilogy in the Lachlan Orogen, and Geochemical Contrasts with A-type Granites in Nigeria: Implications for Petrogenesis and Tectonic Discrimination. Geol. Soc. Lond. Spec. Publications 491, 1. doi:10.1144/ SP491-2018-159

Corfu, F., Hanchar, J. M., Hoskin, P. W. O., and Kinny, P. (2003). 16. Atlas of Zircon Textures. Rev. Mineralogy Geochem. 53, 469-502. doi:10.2113/ 053046910.1515/9781501509322-019

Cox, K. G., Bell, J. D., and Pankhurst, R. J. (1979). The Interpretation of Igneous Rocks. London: Allen \& Unwin. pp. 450.

Dall'Agnol, R., and de Oliveira, D. C., (2007). Oxidized, Magnetite-Series, Rapakivi-type Granites of Carajás, Brazil: Implications for Classification and Petrogenesis of A-type Granites. Lithos 93, 215-233. doi:10.1016/ j.lithos.2006.03.065

Dong, S., Li, Z., and Jiang, L. (2016). The Early Paleozoic Sedimentary-Tectonic Evolution of the Circum-Mangar Areas, Tarim Block, NW China: Constraints from Integrated Detrital Records. Tectonophysics 682, 17-34. doi:10.1016/ j.tecto.2016.05.047

Dumitru, T. A., Zhou, D., Chang, E. Z., Graham, S. A., Hendrix, M. S., Sobel, E. R., et al. (2001). "Uplift, Exhumation, and Deformation in the Chinese Tian Shan," in Paleozoic and Mesozoic Tectonic Evolution of Central Asia: From Continental Assembly to Intracontinental Deformation. Editors M. S. Hendrix and G. A. Davis, 194, 71-99. doi:10.1130/0-8137-1194-0.71

Eby, G. N. (1992). Chemical Subdivision of the A-type granitoids:Petrogenetic and Tectonic Implications. Geol. 20, 641-644. doi:10.1130/0091-7613(1992) $020<0641$ :csotat $>2.3 . c 0 ; 2$

Fisher, C. M., Vervoort, J. D., and Hanchar, J. M. (2014). Guidelines for Reporting Zircon Hf Isotopic Data by LA-MC-ICPMS and Potential Pitfalls in the Interpretation of These Data. Chem. Geology 363, 125-133. doi:10.1016/ j.chemgeo.2013.10.019

Fu, Y., Ding, Q. F., and Wu, C. Z. (2018). Sedimentary Provenance and Age of the Ore-Hosting Strata in the Awanda Gold deposit in the Southwest Tianshan Area, Xinjiang: Constraints from Detrital Zircon U-Pb Dating. Geol. J. China Universities 24, 353-370. (in Chinese with English abstract).

Gao, J., and Klemd, R. (2000). Eclogite Occurrences in the Southern Tianshan High-Pressure belt, Xinjiang, Western China. Gondwana Res. 3, 33-38. doi:10.1016/S1342-937X(05)70055-1
Gao, J., Klemd, R., Qian, Q., Zhang, X., Li, J., Jiang, T., et al. (2011). The Collision between the Yili and Tarim Blocks of the Southwestern Altaids: Geochemical and Age Constraints of a Leucogranite dike Crosscutting the HP-LT Metamorphic belt in the Chinese Tianshan Orogen. Tectonophysics 499, 118-131. doi:10.1016/j.tecto.2011.01.001

Gao, J., Li, M. S., Xiao, X. C., Tang, Y. Q., and He, G. Q. (1998). Paleozoic Tectonic Evolution of the Tianshan Orogen, Northwestern China. Tectonophysics 287, 213-231. doi:10.1016/s0040-1951(97)00211-4

Gao, J., Long, L., Klemd, R., Qian, Q., Liu, D., Xiong, X., et al. (2009). Tectonic Evolution of the South Tianshan Orogen and Adjacent Regions, NW China: Geochemical and Age Constraints of Granitoid Rocks. Int. J. Earth Sci. (Geol. Rundsch) 98, 1221-1238. doi:10.1007/s00531-008-0370-8

Ge, R., Wilde, S. A., Kemp, A. I. S., Jeon, H., Martin, L. A. J., Zhu, W., et al. (2020). Generation of Eoarchean continental Crust from Altered Mafic Rocks Derived from a Chondritic Mantle: The $~ 3.72$ Ga Aktash Gneisses, Tarim Craton (NW China). Earth Planet. Sci. Lett. 538, 116225. doi:10.1016/ j.epsl.2020.116225

Griffin, W. L., Pearson, N. J., Belousova, E., Jackson, S. E., van Achterbergh, E., O'Reilly, S. Y. S., et al. (2000). The Hf Isotope Composition of Cratonic Mantle: LAM-MC-ICPMS Analysis of Zircon Megacrysts in Kimberlites. Geochimica Et Cosmochimica Acta 64, 133-147. doi:10.1016/s0016-7037(99)00343-9

Han, B.-F., He, G.-Q., Wang, X.-C., and Guo, Z.-J. (2011). Late Carboniferous Collision between the Tarim and Kazakhstan-Yili Terranes in the Western Segment of the South Tian Shan Orogen, Central Asia, and Implications for the Northern Xinjiang, Western China. Earth-Science Rev. 109, 74-93. doi:10.1016/ j.earscirev.2011.09.001

Han, Y., Zhao, G., Cawood, P. A., Sun, M., Liu, Q., and Yao, J. (2019). Plumemodified Collision Orogeny: The Tarim-Western Tianshan Example in Central Asia. Geology 47, 1001-1005. doi:10.1130/G46855.1

Han, Y., Zhao, G., Sun, M., Eizenhöfer, P. R., Hou, W., Zhang, X., et al. (2016). Late Paleozoic Subduction and Collision Processes during the Amalgamation of the Central Asian Orogenic Belt along the South Tianshan Suture Zone. Lithos 246247, 1-12. doi:10.1016/j.lithos.2015.12.016

He, Z.-Y., Klemd, R., Zhang, Z.-M., Zong, K.-Q., Sun, L.-X., Tian, Z.-L., et al. (2015). Mesoproterozoic continental Arc Magmatism and Crustal Growth in the Eastern Central Tianshan Arc Terrane of the Southern Central Asian Orogenic Belt: Geochronological and Geochemical Evidence. Lithos 236-237, 74-89. doi:10.1016/j.lithos.2015.08.009

Hegner, E., Alexeiev, D. V., Willbold, M., Kröner, A., Topuz, G., and Mikolaichuk, A. V. (2020). Early Silurian Tholeiitic-Boninitic Mailisu Ophiolite, South Tianshan, Kyrgyzstan: a Geochemical Record of Subduction Initiation. Int. Geology Rev. 62, 320-337. doi:10.1080/00206814.2019.1610670

Hegner, E., Klemd, R., Kroner, A., Corsini, M., Alexeiev, D. V., Iaccheri, L. M., et al. (2011). Mineral Ages and P-T Conditions of Late Paleozoic High-Pressure Eclogite and Provenance of Melange Sediments from Atbashi in the South Tianshan Orogen of Kyrgyzstan. Am. J. Sci. 310, 916-950. doi:10.2475/ 09.2010.07

Huang, H., Wang, T., Qin, Q., Tong, Y., Guo, L., and Zhang, L. (2015a). Geochronology and Zircon Hf Isotopes of Baleigong Granitic Pluton in the Western Part of the South Tianshan Mountains: Petrogenesis and Implication for Tectonic Evolution. Acta Petrologica and Mineralogica 34, 971-990. (in Chinese with English abstract).

Huang, H., Zhang, Z., Kusky, T., Santosh, M., Zhang, S., Zhang, D., et al. (2012). Continental Vertical Growth in the Transitional Zone between South Tianshan and Tarim, Western Xinjiang, NW China: Insight from the Permian Halajun A1-type Granitic Magmatism. Lithos 155, 49-66. doi:10.1016/ j.lithos.2012.08.014

Huang, H., Zhang, Z., Santosh, M., Cheng, Z., and Wang, T. (2018). Crustal Evolution in the South Tianshan Terrane: Constraints from Detrital Zircon Geochronology and Implications for continental Growth in the Central Asian Orogenic Belt. Geol. J. 54, 1379-1400. doi:10.1002/gj.3235

Huang, H., Zhang, Z., Santosh, M., Zhang, D., and Wang, T. (2015b). Petrogenesis of the Early Permian Volcanic Rocks in the Chinese South Tianshan: Implications for Crustal Growth in the Central Asian Orogenic Belt. Lithos 228-229, 23-42. doi:10.1016/j.lithos.2015.04.017

Huang, Z., Long, X., Wang, X.-C., Zhang, Y., Du, L., Yuan, C., et al. (2017). Precambrian Evolution of the Chinese Central Tianshan Block: Constraints on its Tectonic Affinity to the Tarim Craton and Responses to 
Supercontinental Cycles. Precambrian Res. 295, 24-37. doi:10.1016/ j.precamres.2017.04.014

Huo, H., Chen, Z., Zhang, Q., Han, F., and Zhang, W. (2019). Detrital Zircon Ages and Hf Isotopic Compositions of Metasedimentary Rocks in the Wuqia Area of Southwest Tianshan, NW China: Implications for the Early Paleozoic Tectonic Evolution of the Tianshan Orogenic belt. Int. Geology Rev. 61, 2036-2056. doi:10.1080/00206814.2019.1579055

Jiang, T., Gao, J., Klemd, R., Qian, Q., Zhang, X., Xiong, X., et al. (2014). Paleozoic Ophiolitic Mélanges from the South Tianshan Orogen, NW China: Geological, Geochemical and Geochronological Implications for the Geodynamic Setting. Tectonophysics 612-613, 106-127. doi:10.1016/j.tecto.2013.11.038

King, P. L., White, A. J. R., Chappell, B. W., and Allen, C. M. (1997). Characterization and Origin of Aluminous A-type Granites from the Lachlan Fold Belt, Southeastern Australia. J. Petrology 38, 371-391. doi:10.1093/petroj/38.3.371

Konopelko, D., Biske, G., Seltmann, R., Eklund, O., and Belyatsky, B. (2007). Hercynian post-collisional A-type Granites of the Kokshaal Range, Southern Tien Shan, Kyrgyzstan. Lithos 97, 140-160. doi:10.1016/ j.lithos.2006.12.005

Konopelko, D., Seltmann, R., Biske, G., Lepekhina, E., and Sergeev, S. (2009). Possible Source Dichotomy of Contemporaneous post-collisional Barren I-type versus Tin-Bearing A-type Granites, Lying on Opposite Sides of the South Tien Shan Suture. Ore Geology Rev. 35, 206-216. doi:10.1016/ j.oregeorev.2009.01.002

Li, D., He, D., Tang, Y., Wu, X., Lian, Y., and Yang, Y. (2015a). Dynamic Processes from Plate Subduction to Intracontinental Deformation: Insights from the Tectono-Sedimentary Evolution of the Zhaosu-Tekesi Depression in the Southwestern Chinese Tianshan. J. Asian Earth Sci. 113, 728-747. doi:10.1016/j.jseaes.2015.09.007

Li, N.-B., Niu, H.-C., Shan, Q., and Yang, W.-B. (2015b). Two Episodes of Late Paleozoic A-type Magmatism in the Qunjisayi Area, Western Tianshan: Petrogenesis and Tectonic Implications. J. Asian Earth Sci. 113, 238-253. doi:10.1016/j.jseaes.2014.12.015

Li, P., Sun, M., Rosenbaum, G., Yuan, C., Safonova, I., Cai, K., et al. (2018). Geometry, Kinematics and Tectonic Models of the Kazakhstan Orocline, Central Asian Orogenic Belt. J. Asian Earth Sci. 153, 42-56. doi:10.1016/ j.jseaes.2017.07.029

Li, Y. J., Sun, L. D., Wu, H. R., Zhang, G. Y., Wang, G. L., and Huang, Z. B. (2005). Permo-Carboniferous Radiolarians from the Wupata'erkan Group, Western South Tianshan, Xinjiang, China. Acta Geologica Sinica 79, 16-23. doi:10.1111/ j.1755-6724.2005.tb00863.x

Lin, W., Chu, Y., Ji, W., Zhang, Z., Shi, Y., Wang, Z., et al. (2013). Geochronological and Geochemical Constraints for a Middle Paleozoic continental Arc on the Northern Margin of the Tarim Block: Implications for the Paleozoic Tectonic Evolution of the South Chinese Tianshan. Lithosphere 5, 355-381. doi:10.1130/ L231.1

Liu, D., Guo, Z., Jolivet, M., Cheng, F., Song, Y., and Zhang, Z. (2014). Petrology and Geochemistry of Early Permian Volcanic Rocks in South Tian Shan, NW China: Implications for the Tectonic Evolution and Phanerozoic continental Growth. Int. J. Earth Sci. (Geol. Rundsch) 103, 737-756. doi:10.1007/s00531013-0994-1

Liu, D., Jolivet, M., Yang, W., Zhang, Z., Cheng, F., Zhu, B., et al. (2013). ZhuLatest Paleozoic-Early Mesozoic basin-range Interactions in South Tian Shan (Northwest China) and Their Tectonic Significance: Constraints from Detrital Zircon U-Pb Ages. Tectonophysics 599, 197-213. doi:10.1016/ j.tecto.2013.04.018

Liu, Y., Gao, S., Hu, Z., Gao, C., Zong, K., and Wang, D. (2010). Continental and Oceanic Crust Recycling-Induced Melt-Peridotite Interactions in the TransNorth China Orogen: U-Pb Dating, Hf Isotopes and Trace Elements in Zircons from Mantle Xenoliths. J. Petrology 51, 537-571. doi:10.1093/ petrology/egp082

Long, L. L., Gao, J., Wang, J. B., Qian, Q., Xiong, X. M., and Wang, Y. (2008). Geochemistry and SHRIMP Zircon U-Pb Age of post-collisional Granites in the Southwest Tianshan Orogenic belt of China: Examples from the Heiyingshan and Laohutai Plutons. Acta Geologica Sinica (English Edition) $82,415-424$.

Long, X., Yuan, C., Sun, M., Zhao, G., Xiao, W., Wang, Y., et al. (2010). Archean Crustal Evolution of the Northern Tarim Craton, NW China: Zircon U-Pb and
Hf Isotopic Constraints. Precambrian Res. 180, 272-284. doi:10.1016/ j.precamres.2010.05.001

Ludwig, K. (2003). User's Manual for Isoplot/EX Version 3.00 A Geochronological Toolkit for Microsoft Excel Berkeley Geochronology Center. Spec. Publ. 4, 1-70.

Ma, X., Shu, L., and Meert, J. G. (2015). Early Permian Slab Breakoff in the Chinese Tianshan belt Inferred from the post-collisional Granitoids. Gondwana Res. 27, 228-243. doi:10.1016/j.gr.2013.09.018

Maniar, P. D., and Piccoli, P. M. (1989). Tectonic Discrimination of Granitoids. Geol. Soc. America Bull. 101, 635-643. doi:10.1130/0016-7606(1989)101<0635: tdog $>2.3 . \mathrm{co} ; 2$

Mao, Q., Ao, S., Windley, B. F., Zhang, Z., Song, D., Zhang, J. e., et al. (2021). Petrogenesis of Late Carboniferous-Early Permian Mafic-Ultramafic-Felsic Complexes in the Eastern Central Tianshan, NW China: The Result of Subduction-Related Transtension? Gondwana Res. 95, 72-87. doi:10.1016/ j.gr.2021.03.007

Paton, C., Woodhead, J. D., Hellstrom, J. C., Hergt, J. M., Greig, A., and Maas, R. (2010). Improved Laser Ablation U-Pb Zircon Geochronology through Robust Downhole Fractionation Correction. Geochem. Geophys. Geosystems 11, Q0AA06. doi:10.1029/2009GC002618

Peccerillo, A., and Taylor, S. R. (1976). Geochemistry of Eocene Calc-Alkaline Volcanic Rocks from the Kastamonu Area, Northern Turkey. Contr. Mineral. Petrol. 58, 63-81. doi:10.1007/BF00384745

Qin, Q., Huang, H., Wang, T., Guo, R., Zhang, Z., and Tong, Y. (2016). Relationship of the Tarim Craton to the Central Asian Orogenic Belt: Insights from Devonian Intrusions in the Northern Margin of Tarim Craton, China. Int. Geology Rev. 58, 2007-2028. doi:10.1080/ 00206814.2016.1199289

Qin, Q., Wang, T., Huang, H., Zhang, Z., Tong, Y., Song, P., et al. (2021). Late Carboniferous and Early Permian Garnet-Bearing Granites in the South Tianshan Belt, NW China: Two Late Paleozoic Magmatic Events and Implications for Crustal Reworking. J. Asian Earth Sci. 220, 104923. doi:10.1016/j.jseaes.2021.104923

Safonova, I., Biske, G., Romer, R. L., Seltmann, R., Simonov, V., and Maruyama, S. (2016). Middle Paleozoic Mafic Magmatism and Ocean Plate Stratigraphy of the South Tianshan, Kyrgyzstan. Gondwana Res. 30, 236-256. doi:10.1016/ j.gr.2015.03.006

Safonova, I., Kotlyarov, A., Krivonogov, S., and Xiao, W. (2017). Intra-oceanic Arcs of the Paleo-Asian Ocean. Gondwana Res. 50, 167-194. doi:10.1016/ j.gr.2017.04.005

Sang, M., Xiao, W., Bakirov, A., Orozbaev, R., Sakiev, K., and Zhou, K. (2017). Oblique Wedge Extrusion of UHP/HP Complexes in the Late Triassic: Structural Analysis and Zircon Ages of the Atbashi Complex, South Tianshan, Kyrgyzstan. Int. Geology Rev. 59, 1369-1389. doi:10.1080/ 00206814.2016.1241163

Sang, M., Xiao, W., Feng, Q., and Windley, B. F. (2020a). Radiolarian Age and Geochemistry of Cherts from the Atbashi Accretionary Complex, Kyrgyz South Tianshan. Geol. J. 55, 8329-8338. doi:10.1002/gj.3952

Sang, M., Xiao, W., Orozbaev, R., Bakirov, A., Sakiev, K., Pak, N., et al. (2018). Structural Styles and Zircon Ages of the South Tianshan Accretionary Complex, Atbashi Ridge, Kyrgyzstan: Insights for the Anatomy of Ocean Plate Stratigraphy and Accretionary Processes. J. Asian Earth Sci. 153, 9-41. doi:10.1016/j.jseaes.2017.07.052

Sang, M., Xiao, W., and Windley, B. F. (2020b). Unravelling a Devonian-Triassic Seamount Chain in the South Tianshan High-pressure/ultrahigh-pressure Accretionary Complex in the Atbashi Area (Kyrgyzstan). Geol. J. 55, 2300-2317. doi:10.1002/gj.3776

Seltmann, R., Konopelko, D., Biske, G., Divaev, F., and Sergeev, S. (2011). Hercynian post-collisional Magmatism in the Context of Paleozoic Magmatic Evolution of the Tien Shan Orogenic belt. J. Asian Earth Sci. 42, 821-838. doi:10.1016/j.jseaes.2010.08.016

Sengör, A. M. C., Natal'In, B. A., and Burtman, V. S. (1993). Evolution of the Altaid Tectonic Collage and Palaeozoic Crustal Growth in Eurasia. Nature 364, 299-307. doi:10.1038/364299a0

Shu, L. S., Deng, X. L., Zhu, W. B., Ma, D. S., and Xiao, W. J. (2011). Precambrian Tectonic Evolution of the Tarim Block, NW China: New Geochronological Insights from the Quruqtagh Domain. J. Asian Earth Sci. 42, 774-790. doi:10.1016/j.jseaes.2010.08.018 
Su, W. B., Cai, K. D., Sun, M., Wang, X. S., Bao, Z., and He, Z. (2021). Carboniferous Back-Arc Extension in the Southern Yili-Central Tianshan Block and its Significance to the Formation of the Kazakhstan Orocline: Insights from the Wusun Mountain Volcanic belt. Int. J. Earth Sci. 1, 1. doi:10.1007/s00531-021-02111-y

Su, Y., Zheng, J., Liang, L., Dai, H., Zhao, J., Chen, M., et al. (2019). Derivation of A1-type Granites by Partial Melting of Newly Underplated Rocks Related with the Tarim Mantle Plume. Geol. Mag. 156, 409-429. doi:10.1017/ S0016756817000838

Sun, S.-S., and McDonough, W. F. (1989). Chemical and Isotopic Systematics of Oceanic Basalts: Implications for Mantle Composition and Processes. Geol. Soc. Lond. Spec. Publications 42, 313-345. doi:10.1144/ gsl.sp.1989.042.01.19

Tang, G.-J., Chung, S.-L., Wang, Q., Wyman, D. A., Dan, W., Chen, H.-Y., et al. (2014). Petrogenesis of a Late Carboniferous Mafic dike-granitoid Association in the Western Tianshan: Response to the Geodynamics of Oceanic Subduction. Lithos 202-203, 85-99. doi:10.1016/j.lithos.2014.04.010

Wan, B., Wang, X., Liu, X., Cai, K., Xiao, W., and Mitchell, R. N. (2020). Long-lived Seamount Subduction in Ancient Orogens: Evidence from the Paleozoic South Tianshan. Geology 49, 531-535. doi:10.1130/G48547.1

Wang, B., Shu, L., Faure, M., Jahn, B.-m., Cluzel, D., Charvet, J., et al. (2011). Paleozoic Tectonics of the Southern Chinese Tianshan: Insights from Structural, Chronological and Geochemical Studies of the Heiyingshan Ophiolitic Mélange (NW China). Tectonophysics 497, 85-104. doi:10.1016/ j.tecto.2010.11.004

Wang, C., Liu, L., Luo, J. H., Che, Z. C., Teng, Z. H., and Cao, X. (2007b). Late Paleozoic post-collisional Magmatism in the Southwestern Tianshan Orogenic belt, Take the Baleigong Pluton in the Kokshal Region as an Example. Acta Petrologica Sinica 23, 1830-1840. (in Chinese with English absctract)

Wang, H. L. (2007a). Geological Map of Chinese Tianshan and Adjacent Areas (Scale 1:1,000,000), Xi'an, China: Xi'an Center of China Geological Survey.

Wang, X.-S., Klemd, R., Gao, J., Jiang, T., Li, J.-L., and Xue, S.-C. (2018b). Final Assembly of the Southwestern Central Asian Orogenic Belt as Constrained by the Evolution of the South Tianshan Orogen: Links with Gondwana and Pangea. J. Geophys. Res. Solid Earth 123, 7361-7388. doi:10.1029/ 2018JB015689

Wang, X.-S., Zhang, X., Gao, J., Li, J.-L., Jiang, T., and Xue, S.-C. (2018a). A Slab Break-Off Model for the Submarine Volcanic-Hosted Iron Mineralization in the Chinese Western Tianshan: Insights from Paleozoic Subduction-Related to post-collisional Magmatism. Ore Geology Rev. 92, 144-160. doi:10.1016/ j.oregeorev.2017.11.015

Wang, X. S., Cai, K. D., Sun, M., Zhao, G. C., Xiao, W. J., and Xia, X. P. (2020). Evolution of Late Paleozoic Magmatic Arc in the Yili Block, NW China: Implications for Oroclinal Bending in the Western Central Asian Orogenic Belt. Tectonics 39, e2019TC005822. doi:10.1029/2019TC005822

Watson, E. B., and Harrison, T. M. (1983). Zircon Saturation Revisited: Temperature and Composition Effects in a Variety of Crustal Magma Types. Earth Planet. Sci. Lett. 64, 295-304. doi:10.1016/0012-821x(83) 90211-x

Wei, X., Xu, Y.-G., He, B., Zhang, L., Xia, X.-P., and Shi, X.-F. (2019). Zircon U-Pb Age and Hf-O Isotope Insights into Genesis of Permian Tarim Felsic Rocks, NW China: Implications for Crustal Melting in Response to a Mantle Plume. Gondwana Res. 76, 290-302. doi:10.1016/j.gr.2019.06.015

Wei, X., and Xu, Y. G. (2011). Petrogenesis of Xiaohaizi Syenite Complex from Bachu Area, Tarim. Acta Petrologica Sinica 27, 2984-3004. (in Chinese with English abstract).

Wen, L., Li, C., Li, H. H., Liu, Y. L., Li, Y. J., Zhao, Y., et al. (2020). The Collision-Related Structures Revealed in the Northern Tarim Basin and Their Geological Significance. Geol. J. 55, 3054-3069. doi:10.1002/ gj. 3561

Whalen, J. B., Currie, K. L., and Chappell, B. W. (1987). A-type Granites: Geochemical Characteristics, Discrimination and Petrogenesis. Contrib. Mineral. Petrol. 95, 407-419. doi:10.1007/BF00402202

Wiedenbeck, M., Allé, P., Corfu, F., Griffin, W. L., Meier, M., Oberli, F., et al. (1995). Three Natural Zircon Standards for U-Th-Pb, Lu-Hf, Trace Element and REE Analyses. Geostandards Newsl. 19, 1-23. doi:10.1111/j.1751908X.1995.tb00147.x

Windley, B. F., Alexeiev, D., Xiao, W., Kröner, A., and Badarch, G. (2007). Tectonic Models for Accretion of the Central Asian Orogenic Belt. J. Geol. Soc. 164, 31-47. doi:10.1144/0016-76492006-022

Wu, F., Liu, X., Ji, W., Wang, J., and Yang, L. (2017). Highly Fractionated Granites: Recognition and Research. Sci. China Earth Sci. 60, 1201-1219. doi:10.1007/ s11430-016-5139-1

Xiao, W., Han, C., Liu, W., Wan, B., Zhang, J. E., Ao, S., et al. (2014). How many Sutures in the Southern Central Asian Orogenic Belt: Insights from East Xinjiang-West Gansu (NW China)? Geosci. Front. 5, 525-536. doi:10.1016/ j.gsf.2014.04.002

Xiao, W. J., Windley, B. F., Hao, J., and Zhai, M. G. (2003). Accretion Leading to Collision and the Permian Solonker Suture, Inner Mongolia, China: Termination of the Central Asian Orogenic belt. Tectonics 22, 2069-1089. doi:10.1029/2002tc001484

Xiao, W. J., Windley, B. F., Huang, B. C., Han, C. M., Yuan, C., Chen, H. L., et al. (2009). End-Permian to Mid-triassic Termination of the Accretionary Processes of the Southern Altaids: Implications for the Geodynamic Evolution, Phanerozoic continental Growth, and Metallogeny of Central Asia. Int. J. Earth Sci. (Geol. Rundsch) 98, 1189-1217. doi:10.1007/s00531008-0407-z

Xiao, W., Song, D., Windley, B. F., Li, J., Han, C., Wan, B., et al. (2020). Accretionary Processes and Metallogenesis of the Central Asian Orogenic Belt: Advances and Perspectives. Sci. China Earth Sci. 63, 329-361. doi:10.1007/s11430-019-9524-6

Xiao, W., Windley, B. F., Allen, M. B., and Han, C. (2013). Paleozoic Multiple Accretionary and Collisional Tectonics of the Chinese Tianshan Orogenic Collage. Gondwana Res. 23, 1316-1341. doi:10.1016/ j.gr.2012.01.012

Xiao, W., Windley, B. F., Sun, S., Li, J., Huang, B., Han, C., et al. (2015). A Tale of Amalgamation of Three Permo-Triassic Collage Systems in Central Asia: Oroclines, Sutures, and Terminal Accretion. Annu. Rev. Earth Planet. Sci. 43, 477-507. doi:10.1146/annurev-earth-060614-105254

Xu, X.-Y., Wang, H.-L., Li, P., Chen, J.-L., Ma, Z.-P., Zhu, T., et al. (2013). Geochemistry and Geochronology of Paleozoic Intrusions in the Nalati (Narati) Area in Western Tianshan, Xinjiang, China: Implications for Paleozoic Tectonic Evolution. J. Asian Earth Sci. 72, 33-62. doi:10.1016/ j.jseaes.2012.11.023

Yakubchuk, A. (2017). Evolution of the Central Asian Orogenic Supercollage since Late Neoproterozoic Revised Again. Gondwana Res. 47, 372-398. doi:10.1016/ j.gr.2016.12.010

Yang, G., Li, Y., Li, S., Tong, L., Wang, Z., and Wu, L. (2018). Accreted Seamounts in the South Tianshan Orogenic Belt, NW China. Geol. J. 53, 16-29. doi:10.1002/gj.3247

Yang, S.-F., Li, Z., Chen, H., Santosh, M., Dong, C.-W., and Yu, X. (2007). Permian Bimodal Dyke of Tarim Basin, NW China: Geochemical Characteristics and Tectonic Implications. Gondwana Res. 12, 113-120. doi:10.1016/ j.gr.2006.10.018

Yin, J., Chen, W., Xiao, W., Yuan, C., Long, X., Cai, K., et al. (2016). Late Carboniferous Adakitic Granodiorites in the Qiongkusitai Area, Western Tianshan, NW China: Implications for Partial Melting of Lower Crust in the Southern Central Asian Orogenic Belt. J. Asian Earth Sci. 124, 42-54. doi:10.1016/j.jseaes.2016.04.010

Yin, J. Y., Xiao, W. J., Spencer, C. J., Sun, M., Chen, W., and Huang, H. (2021). The Role and Significance of Juvenile Sediments in the Formation of A-type Granites, West Junggar Oceanic Arc (NW China): Zircon Hf-O Isotopic Perspectives. Geol. Soc. America Bull. 133, 1560-1574. doi:10.1130/ B35790.1

Zhang, C.-L., Xu, Y.-G., Li, Z.-X., Wang, H.-Y., and Ye, H.-M. (2010). Diverse Permian Magmatism in the Tarim Block, NW China: Genetically Linked to the Permian Tarim Mantle Plume? Lithos 119, 537-552. doi:10.1016/ j.lithos.2010.08.007

Zhang, C.-L., and Zou, H.-B. (2013). Permian A-type Granites in Tarim and Western Part of Central Asian Orogenic Belt (CAOB): Genetically Related to a Common Permian Mantle Plume? Lithos 172-173, 47-60. doi:10.1016/ j.lithos.2013.04.001 
Zhang, C. L., Li, X. H., Li, Z. X., Ye, H. M., and Li, C. N. (2008). A Permian Layered Intrusive Complex in the Western Tarim Block, Northwestern China: Product of a Ca. 275-Ma Mantle Plume? J. Geology. 116, 269-287. doi:10.1086/587726

Zhang, L., Wang, Y., Zhang, L., and Lü, Z. (2019a). Ultrahigh Pressure Metamorphism and Tectonic Evolution of Southwestern Tianshan Orogenic belt, China: a Comprehensive Review. Geol. Soc. Lond. Spec. Publications 474, 133-152. doi:10.1144/SP474.12

Zhang, L., Zhu, J., Xia, B., Zhang, C., and Zhang, L. (2019b). Metamorphism and Zircon Geochronological Studies of Metagabbro Vein in the Yushugou Granulite-Peridotite Complex from South Tianshan, China. J. Earth Sci. 30, 1215-1229. doi:10.1007/s12583-019-1254-5

Zou, S.-Y., Li, Z.-L., Song, B., Ernst, R. E., Li, Y.-Q., Ren, Z.-Y., et al. (2015). Zircon $\mathrm{U}-\mathrm{Pb}$ Dating, Geochemistry and Sr-Nd-Pb-Hf Isotopes of the Wajilitag Alkali Mafic Dikes, and Associated Diorite and Syenitic Rocks: Implications for Magmatic Evolution of the Tarim Large Igneous Province. Lithos 212-215, 428-442. doi:10.1016/j.lithos.2014.09.005
Conflict of Interest: The authors declare that the research was conducted in the absence of any commercial or financial relationships that could be construed as a potential conflict of interest.

Publisher's Note: All claims expressed in this article are solely those of the authors and do not necessarily represent those of their affiliated organizations, or those of the publisher, the editors and the reviewers. Any product that may be evaluated in this article, or claim that may be made by its manufacturer, is not guaranteed or endorsed by the publisher.

Copyright (c) 2022 Abuduxun, Xiao, Windley, Huang, Yang, Gan, Sang and Liu. This is an open-access article distributed under the terms of the Creative Commons Attribution License (CC BY). The use, distribution or reproduction in other forums is permitted, provided the original author(s) and the copyright owner(s) are credited and that the original publication in this journal is cited, in accordance with accepted academic practice. No use, distribution or reproduction is permitted which does not comply with these terms. 